\title{
Assessing the interconnectedness and systemic risk contagion in the Chinese banking network
}

\author{
Ming Qi, Danyang Shi, Shaoyi Feng, Pei Wang and \\ Amuji Bridget Nnenna \\ School of Economics and Management, China University of Petroleum, Beijing, China
}

Risk contagion in Chinese banking network

\begin{abstract}
Purpose - In this paper, the authors use the balance sheet data to investigate the interconnectedness and risk contagion effects in China's banking sector. They firstly study the network structure and centrality of the interbank network. Then, they investigate how and to what extent the credit shock and liquidity shock can lead to the risk propagation in the banking network.

Design/methodology/approach - Referring to the theoretical framework by Haldane and May (2011), this paper uses the network topology theory to analyze the contagion mechanism of credit shock and liquidity shock. Centrality measures and log-log plot are used to evaluate the interconnectedness of China's banking network.

Findings - The network topology has shown clustering effects of large banks in China's financial network. If the Industrial and Commercial Bank of China (ICBC) is in distress, the credit shock has little impact on the Chinese banking sector. However, the liquidity shock has shown more substantial effects than that of the credit shock. The discount rate and the rollover ratio play significant roles in determining the contagion effects. If the credit shock and liquidity shock coincide, the contagion effects will be amplified.

Research limitations/implications - The results of this paper reveal the network structure of China's interbank market and the resilience of banking system to the adverse shock. The findings are valuable for regulators to make policies and supervise the systemic important banks.

Originality/value - The balance sheet data of different types of banks are used to construct a bilateral exposure matrix. Based on the matrix, this paper investigates the knock-on effects of credit shock triggered by the debt default in the interbank market, the knock-on effects of liquidity effects, which is featured by "fire sale" of bank assets, and the contagion effects of combined shocks.
\end{abstract}

Keywords Risk contagion, Interbank market, Network topology, Credit shock, Liquidity shock

Paper type Research paper

\section{Introduction}

China's banking system is characterized by the complex and diverse participants, including policy banks, state-owned commercial banks, joint-stock banks, urban commercial banks, rural commercial banks and foreign banks. Furthermore, several state-owned and local asset management companies are established to deal with non-performing loans. With more diversified participants involved in the financial market, the complexity of China's interbank market has increased significantly. Since 2008, Industrial and Commercial Bank of China (ICBC), China Construction Bank (CCB) and Bank of China (BOC) have become the top three

(C) Ming Qi, Danyang Shi, Shaoyi Feng, Pei Wang and Amuji Bridget Nnenna. Published by Emerald Publishing Limited. This article is published under the Creative Commons Attribution (CC BY 4.0) licence. Anyone may reproduce, distribute, translate and create derivative works of this article (for both commercial and non-commercial purposes), subject to full attribution to the original publication and authors. The full terms of this licence may be seen at http://creativecommons.org/licences/by/4.0/ legalcode

Funding: This research is supported by the National Social Science Fund of China (20BJY233).

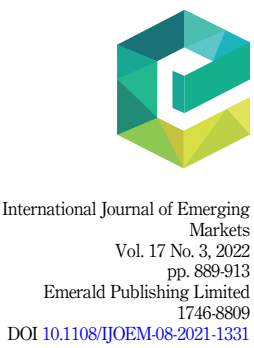


IJOEM

17,3

890

banks in the world [1]. In 2020, the average loans of commercial banks hit 542601.2 billion yuan, which accounted for a considerable proportion of China's GDP [2]. With the rapid development of financial innovation, the transactions among banks keep increasing sharply, which makes the financial market more complex. From the fourth quarter of 2015 to the third quarter of 2020, the lending amount of China's interbank market shows an overall upward trend, with a $70 \%$ increase in lending and a $62 \%$ increase in borrowing, as shown in Figure 1. It indicates that the scale of the interbank market and the degree of connection are increasing quickly. In addition, the proportion of transactions of Chinese banks in the global banking market is also growing. China's interbank borrowing and lending accounted for $5.89 \%$ and $5.17 \%$ of the world's total in the fourth quarter of 2015 , respectively, and rose to $8.37 \%$ and $6.84 \%$ in the third quarter of 2020. China's interbank market is becoming more and more complex and playing a significant role in the global banking system.

The stock market fluctuation in 2015 caused the market value of several listed banks to decline, which had a significant impact on the banking industry. For a long time, China's banking industry has been subject to strict supervision and a high deposit reserve ratio. However, Hainan development bank went bankrupt in 1998 and resulted in 445 million-yuan loss. The People's Bank of China and the local government provided a 4.7 billion yuan bailout. In 2019, the capital adequacy ratio of Baoshang Bank became insufficient. This event led to the default of 6.5 billion yuan bonds and 586 million yuan interests, which brought about the shortterm liquidity impact on the financial market. Fujian Haixia Bank, another city commercial bank, had to cancel the issuance of secondary capital bonds. Therefore, it is necessary to pay more attention to the contagion of systemic risks in China's financial industry.

In November 2018, the Financial Stability Council (FBS) announced the global systemically important banks (GSIB). ICBC, BOC, CCB and Agricultural Bank of China (ABC) were all listed as systemically important banks. In November 2019, the People's Bank of China, the China Banking and Insurance Regulatory Commission and the China Securities Regulatory Commission jointly issued guiding regulations on improving the supervision of systemically important financial institutions. According to the regulation, the systemically important banks are categorized into five groups and required to maintain additional capital to improve the stability of the banking system [3]. All these policies have implied that the systemic risk contagion is of great concern by both academic and regulators. This paper investigates how the systemic risk arises and to what extent the systemic risk can undermine the banking sector stability. The remainder of this paper is organized as follows: Section 2 discusses relevant literature on systemic risk contagion. Section 3 presents the theoretical framework of risk contagion from the perspective of balance sheet. Section 4 examines the network structure and measures the interconnectedness. Section 5 illustrates the contagion effects of credit and liquidity shocks in the banking sector. The last section finishes with the conclusion and discussion of policy implications.

Figure 1.

Total interbank transaction volume of China and World
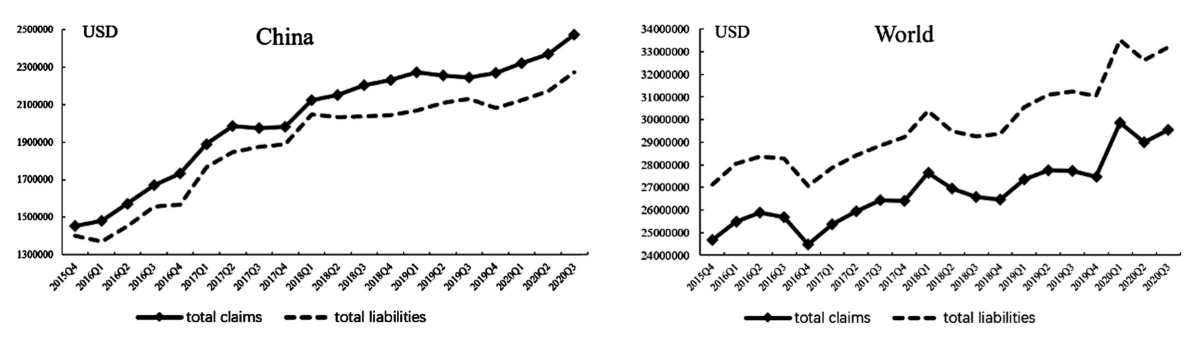

Source(s): BIS statistics 


\section{Literature review}

Since the subprime crisis in 2008, there have been increasing interests in researching the propagation of systemic risks by academics and practitioners. Many scholars have employed various methods to investigate the systemic risks in global financial markets. Among all these methods, the complex network is widely used in the analysis of the contagion of systemic risk in the financial markets in different countries. Interdisciplinary network analysis and behavioral modeling are helpful tools to investigate financialeconomic stability (Battiston et al., 2016). Based on the theory of ecological complex banking network, Haldane and May (2011) proposed a framework to investigate the fragility of the banking system by the shock of the balance sheet of commercial banks. After that, this simulation method is widely used for the analysis of systemic risk propagation by many academic researchers (Hellwig, 2009; Arinaminpathy et al., 2012; Paltalidis et al., 2015; Chen et al., 2020a, b). In the study of systemic risk contagion, an important method is a maximum entropy (MEM) theory, which uses the computational experimental method to investigate the risk contagion effect (Upper, 2011). Based on the assumption that the loan positions of all single financial institutions are evenly distributed in the network, the bilateral loan matrix can be constructed. However, whether the simulated matrix is consistent with the actual bilateral lending data has been questioned. Some researchers believe that there is little difference between the simulated bilateral transactions and the actual lending data. The maximum entropy of bank loan data can be used to approximate the actual bilateral exposure matrix (Paltalidis et al., 2015; Lelyveld and Liedorp, 2006). Due to relationship loans and other factors, Some scholars argued that the simulated transactions matrix may differ from the actual bilateral lending data (Frisell et al., 2007; Mistrulli, 2011; Paltalidis et al., 2015).

Most scholars found that the failure of banks will bring about serious contagion effects, and the failures of banks with larger risk exposure have a more considerable impact and are more likely to lead to systemic risk in the financial network (Blavarg and Nimander, 2002; Lelyveld and Liedorp, 2006; Elsinger et al., 2006; Upper, 2011; Kanno, 2015; Chen et al., 2020a, b; Andries and Galasan, 2020). However, some scholars have made different points. Hausenblas et al. (2015) used the actual bilateral bank lending data in the Czech Republic and find that the loss within the financial system is limited after the liquidity shock, which means the banking system is relatively stable with strong liquidity shock resistance. On the other hand, some researchers found that the primary sources of systemic risk are sovereign credit risk, related exposure, mutual credit relationship and wealth effect (Elsinger et al., 2006; Paltalidis et al., 2015; Hellwig, 2009; Bayona and Peia, 2020). In terms of Chinese market, some scholars believe that the higher the proportion of interbank assets, the stronger the contagion effect of credit risk in the banking sector, and large banks were greatly impacted (Chen et al., 2020a, b).

Scholars have used different methods to study the propagation of systemic risk, as shown in Table 1. Hurd (2016) proposed the concept of "bootstrap percolation" to determine the large-scale nature of infectious financial cascades. Ren et al. (2014) applied the "clearing payment concept" to the interbank financial network system, and discussed the impact of asset recovery rate and capital requirements on the existence, uniqueness and continuity of systemic risk. Gorpe et al. (2019) proposed a contagion mapping method to simulate the extensive exposure network of euro area banks. Le (2021) used SRISK to measure the systemic risks of 49 listed banks in six ASEAN countries and argued that the level of systemic risk between 2000 and 2018 was higher than that at the global financial crisis during 2007-2008. Dahir et al. (2018) employed the system generalized method of moments (GMM) technique to examine the effects of funding liquidity risk and found that the liquidity risk is a risk factor which drives the potential bank default. Most previous research has focused on the failure of listed banks under a given risk. However, nonlisted banks also play significant role in the banking sector, which is currently facing various kinds of potential risks simultaneously. Therefore, this research contributes to the literature in
Risk contagion in Chinese banking network 
IJOEM 17,3

892

\begin{tabular}{|c|c|c|c|c|}
\hline & Authors & $\begin{array}{l}\text { Research } \\
\text { area }\end{array}$ & Method & Conclusions \\
\hline & $\begin{array}{l}\text { Amundsen and Elin } \\
(2005)\end{array}$ & Denmark & Maximum entropy & Only small banks are affected by the risk contagion \\
\hline & Elsinger et al. (2006) & England & Maximum entropy & $\begin{array}{l}\text { Two primary sources of systemic risk are relationship } \\
\text { credit and related exposure }\end{array}$ \\
\hline & Hellwig (2009) & USA & Balance sheet shock & $\begin{array}{l}\text { Systemic risk comes from the balance sheet effect, } \\
\text { asset price effect and information contagion effect }\end{array}$ \\
\hline & Upper (2011) & $\backslash$ & Maximum entropy & $\begin{array}{l}\text { The possibility of default contagion is not high, but it } \\
\text { cannot be completely ruled out }\end{array}$ \\
\hline & $\begin{array}{l}\text { Arinaminpathy } \\
\text { et al. }(2012)\end{array}$ & USA & Balance sheet shock & $\begin{array}{l}\text { The importance of large and well-connected banks in } \\
\text { system stability is proportional to the size }\end{array}$ \\
\hline & Gao and Pan (2012) & China & $\begin{array}{l}\text { Maximum entropy and } \\
\text { count model }\end{array}$ & $\begin{array}{l}\text { Under the completely decentralized market structure, } \\
\text { the contagion risk of the interbank market is minimal }\end{array}$ \\
\hline & $\begin{array}{l}\text { Paltalidis et al. } \\
\text { (2015) }\end{array}$ & Euro zone & Maximum entropy & $\begin{array}{l}\text { Sovereign credit risk is the main source of contagion } \\
\text { in the banking network }\end{array}$ \\
\hline & Souza et al. (2015) & Brazil & $\begin{array}{l}\text { Maximum impact chart } \\
\text { and minimum spanning } \\
\text { tree }\end{array}$ & $\begin{array}{l}\text { Scale is not the only determinant of the characters of } \\
\text { the network. Some large financial institutions have } \\
\text { fewer contagion losses than medium-sized } \\
\text { institutions }\end{array}$ \\
\hline & Sun (2020) & China & Maximum entropy & $\begin{array}{l}\text { Bank defaults have the least contagious effect on } \\
\text { China's interbank network }\end{array}$ \\
\hline & Chen et al. $(2020 \mathrm{a}, \mathrm{b})$ & China & Maximum entropy & $\begin{array}{l}\text { The higher the ratio of interbank assets, the stronger } \\
\text { the contagion effects of credit risk }\end{array}$ \\
\hline & Chen et al. $(2020 \mathrm{a}, \mathrm{b})$ & China & Maximum entropy & $\begin{array}{l}\text { The level of contagion caused by liquidity shocks has } \\
\text { shown a clear downward trend }\end{array}$ \\
\hline & $\begin{array}{l}\text { Haldane and May } \\
\text { (2011) }\end{array}$ & & Balance sheet shock & $\begin{array}{l}\text { Proposed the framework to study the impact of risk } \\
\text { on the balance sheet. }\end{array}$ \\
\hline & Feng and Li (2021) & China & $\begin{array}{l}\text { A model with random } \\
\text { shocks }\end{array}$ & $\begin{array}{l}\text { Cross shareholding networks magnify and spread } \\
\text { small but continuous external shocks }\end{array}$ \\
\hline \multirow[t]{3}{*}{$\begin{array}{l}\text { Theoretical } \\
\text { methods }\end{array}$} & Ren et al. (2014) & $\backslash$ & Liquidating payments & $\begin{array}{l}\text { The existence, uniqueness and continuity of financial } \\
\text { networks can be used as the basis of systematic risk } \\
\text { measurement }\end{array}$ \\
\hline & Hurd (2016) & $\backslash$ & Random graph & $\begin{array}{l}\text { Bootstrap percolation is an accurate concept to solve } \\
\text { and understand the cascade growth of simple } \\
\text { networks }\end{array}$ \\
\hline & $\begin{array}{l}\text { Blavarg and } \\
\text { Nimander (2002) }\end{array}$ & Sweden & $\begin{array}{l}\text { Credit risk mitigation of } \\
\text { counterparties }\end{array}$ & $\begin{array}{l}\text { Banks with significant risk exposures are more likely } \\
\text { to cause systemic risks }\end{array}$ \\
\hline \multirow[t]{7}{*}{$\begin{array}{l}\text { Bilateral } \\
\text { transaction } \\
\text { exposure }\end{array}$} & $\begin{array}{l}\text { Lelyveld and } \\
\text { Liedorp (2006) }\end{array}$ & Holland & Maximum entropy & $\begin{array}{l}\text { The bankruptcy of a large bank will bring a } \\
\text { considerable burden to other banks, but it will not } \\
\text { lead to a complete collapse of the market. }\end{array}$ \\
\hline & Frisell et al. (2007) & Sweden & Monte Carlo simulation & $\begin{array}{l}\text { Reconstruct bilateral exposures could underestimate } \\
\text { the risk of default contagion }\end{array}$ \\
\hline & $\begin{array}{l}\text { Memmel and Stein } \\
(2008)\end{array}$ & German & $\begin{array}{l}\text { Round by round } \\
\text { algorithm }\end{array}$ & $\begin{array}{l}\text { The overall risk of interbank contagion is very low, } \\
\text { but contagion may occur if a large bank fails }\end{array}$ \\
\hline & Mistrulli (2011) & Italy & Maximum entropy & $\begin{array}{l}\text { The maximum entropy method overestimates the } \\
\text { effects of contagion }\end{array}$ \\
\hline & Kanno (2015) & Japan & $\begin{array}{l}\text { Maximum entropy } \\
\text { estimation and SIR model }\end{array}$ & $\begin{array}{l}\text { The three global systemically essential banks } \\
\text { overwhelmed other banking groups in terms of } \\
\text { interconnectivity }\end{array}$ \\
\hline & $\begin{array}{l}\text { Hausenblas et al. } \\
\text { (2015) }\end{array}$ & $\begin{array}{l}\text { Czech } \\
\text { Republic }\end{array}$ & Computational model & $\begin{array}{l}\text { The possibility of contagion caused by credit loss of } \\
\text { interbank risk exposure is limited }\end{array}$ \\
\hline & Gorpe et al. (2019) & Euro zone & CoMap & $\begin{array}{l}\text { A critical point at which less fragility spreads to a } \\
\text { highly fragile country is a nonlinear function of the } \\
\text { combination of network structure and bank } \\
\text { characteristics }\end{array}$ \\
\hline \multirow[t]{5}{*}{ Others } & Huynh et al. (2020) & Vietnam & $\begin{array}{l}\text { Chi-plots and Kendall } \\
\text { plots and copula }\end{array}$ & $\begin{array}{l}\text { The risk of each bank may be passed on to other } \\
\text { banks through stock returns }\end{array}$ \\
\hline & $\begin{array}{l}\text { Ahelegbey et al. } \\
(2020)\end{array}$ & Worldwide & VAR model & $\begin{array}{l}\text { Bilateral risk exposure and market prices are both } \\
\text { infectious channels for one country to transmit } \\
\text { shocks to other countries }\end{array}$ \\
\hline & Xlg et al. (2020) & China & $\begin{array}{l}\text { Macro jump and volatility } \\
\text { spillover network }\end{array}$ & $\begin{array}{l}\text { The capital market service industry plays a leading } \\
\text { role in risk contagion, followed by the currency } \\
\text { service industry and the insurance industry }\end{array}$ \\
\hline & Chen et al. (2021) & China & $\begin{array}{l}\text { A model for solvency } \\
\text { contagion risk }\end{array}$ & $\begin{array}{l}\text { Systemic contagion losses of the network are highly } \\
\text { dependent on the perceived exogenous recovery rate }\end{array}$ \\
\hline & Yang et al. (2021) & China & EPU network & China is the Asia-Pacific EPU network's center \\
\hline
\end{tabular}

Table 1.

Important research papers and corresponding methods
Upper (2011)

Arinaminpathy

et al. (2012)

Gao and Pan (2012)

Paltalidis et al

(2015)

Souza et al. (2015)

Sun (2020)

Chen et al. (2020a, b)

dane and Ma

g and $\mathrm{Li}(2021)$

Hurd (2016)

Liedorp (2006)

Frisell et al. (2007)

Memmel and Stein

Kanno (2015)

Hausenblas et al

Republic
Two primary sources of systemic risk are relationship

The possibility of default contagion is not high, but it completely ruled out

banks in Under the completely decentralized market structure, the contagion risk of the interbank market is minimal Sovereign credit risk is the main source of contagion the banking network fewer contagion losses than medium-sized

Bank defaults have the least contagious effect on ion effects of credit ris

level of contagion caused by liquidity shocks has on the balance sheet.

ify and spread mall but continuous external shocks

ystematic risk

Bootstrap percolation is an accurate concept to solve understand the cascade growth of simple

to cause systemic risk iderable burden to other banks, but it will not

the risk of default contagion

The overall risk of interbank contagion is very low, contagion may occur if a large bank fails

overestimates the

A critical point at which less fragility spreads to a istic

banks through stock returns

Bilateral risk exposure and market prices are both infectious channels for one country to transmi

Systemic contagion losses of the network are highly dependent on the perceived exogenous recovery rate is the Asia-Pacific EPU network's center 
twofold. First, this paper uses the data of both listed banks and non-listed banks to discover the speed of risk propagation and the impact of systemic risk. Second, this paper examines the contagion effects of credit risk, liquidity risk and hybrid risk, and finds which kind of risk should be more concerned by the regulator.

\section{Theoretical framework}

The interconnection among financial institutions may trigger the propagation of shocks in the financial network and facilitate the risk contagion. Hellwig (2009) believes that the formation of systemic risk can be attributed to three mechanisms. First, the balance sheet effect, which is a domino effect caused by the contractual relationship. If a financial institution goes bankrupt, it will cause the creditors to write down their contractual claims. Second, asset price effect, which is a domino effect caused by asset devaluation. If a financial institution is in distress, it may have to fire-sale the assets at a lower price and deteriorate the solvency of all financial institutions holding the same assets. Third, information contagion effect. Once the plight of a financial institution is detected, it will result in the concerns of investors and lead to a bank run. Referring to the theoretical framework of Haldane and May (2011), this paper uses the network topology theory to analyze the contagion mechanism of credit shock and liquidity shock. First of all, suppose there are $\mathrm{N}$ banks. Any bank is connected with other banks as a lender or borrower, or both as a lender and a borrower. Each bank is also connected with other $Z$ banks. The banks are interconnected through the lending relationship and form an evenly distributed network. The balance sheet of bank $i$ is shown in Figure 2.

For a given bank $i$, there are two categories of assets: interbank-bank lending $\left(l_{i}\right)$ and external assets $\left(e_{i}\right)$, and two categories of liabilities: interbank-bank borrowing $\left(b_{i}\right)$ and deposits $\left(d_{i}\right)$. The subscripts indicate each specific bank, with $i=1,2, \ldots, N$, where $N$ is the total number of banks. For any individual bank, solvency requires that the amount of assets is higher than that of liabilities, which means:

$$
r_{i} \equiv\left(e_{i}+l_{i}\right)-\left(d_{i}+b_{i}\right) \geq 0
$$

where $r_{i}$ is the "net worth" of bank $i$. If it becomes lower than zero, liabilities exceed assets, and the bank $i$ is assumed to be in distress. Referring to Upper (2011) and Arinaminpathy et al. (2012), once the value of bank equity is negative, the bank is assumed to be bankrupt. In addition, $r_{i}$ is assumed to be a fixed fraction of assets $\left(a_{i}\right)$ (Nasir et al., 2020; Gai and Kapadia,

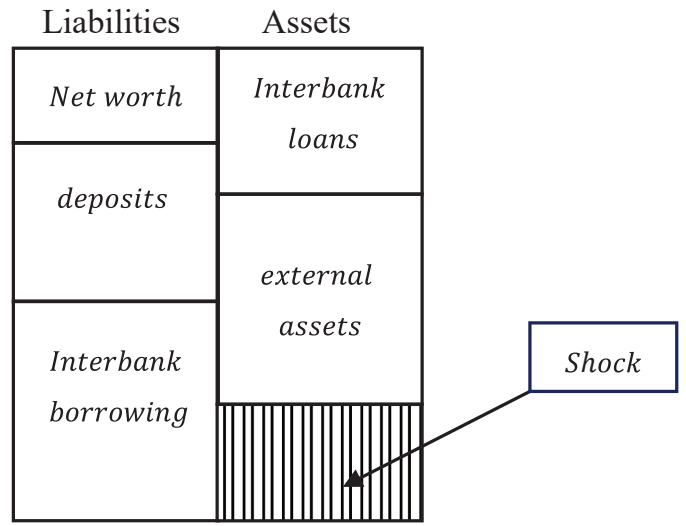

Source(s): Haldane and May, 2011
Risk contagion in Chinese banking network

\section{-}


IJOEM

17,3

2010). In a random Erdős-Rényi network, each bank is linked to any other one with the probability $p$. A bank's average number of outgoing or lending connections is denoted as $z$, which is as follows:

$$
z=p(N-1)
$$

The ratio of all loans of bank $i$ to its total assets is $\theta_{i}$, the ratio of external assets to total assets is then $1-\theta_{i}$. Referring to Haldane and May (2011) and Gai and Kapadia (2010), the total assets of each bank are normalized to be 1 . Total external assets and loans can be denoted as $e=1-\theta_{i}$ and $b=\theta_{i}$. Next, we elaborate on the impact of credit shock and liquidity shock on the banking system.

\subsection{Credit shock}

The initial failure of a given bank can trigger knock-on effects in the financial network. Here it is assumed that the bank in distress can sell remaining assets for the original value. In other words, bank failure will result in the loss of funds borrowed from credit banks but will not affect the remaining assets of banks.

3.1.1 Failure in phase I. Following Nier et al. (2007), Gai and Kapadia (2010) and Haldane and May (2011), a single bank suffers a shock initially. A fraction, denoted as $f$, is wiped out from its external assets. In the normalized framework, the consequence of shocks in the first phase (phase I) can be represented as follows:

$$
S(\mathrm{I})=f(1-\theta)
$$

once $s(\mathrm{I})-\gamma>0$, the bank will be in distress.

3.1.2 Failure in phase II. The failures in phase II are approximately distributed among the remaining solvent banks in the network [4]. If the loss $(s(\mathrm{I})-\gamma)$ is less than the defaulting bank's total borrowing; the loss is then equally distributed among all creditor banks. Otherwise, once the total loss is more than the defaulting bank's total borrowing, each creditor bank loses the total loans. It implies that the default by a given bank can bring about the second-round shock to its $z$ credit banks, that is, phase II. The shock, denoted as $s($ II), is shown as follows:

$$
S(\mathrm{II})=\frac{\min [\theta, s(\mathrm{I})-\gamma]}{z}
$$

Similar to phase I, once $S($ II $)-\gamma>0, z$ banks which are connected with the initially failing bank are in distress. Then, the criterion for the bankruptcy in phase II is as follows:

$$
\min [\theta, f(1-\theta)-\gamma] \geq z \gamma
$$

3.1.3 Failure in phase III. Since the failure of $z$ banks in phase II can make several-round shocks in phase III, it is necessary to consider the probability distribution of $z$. After phase II, the number of remaining banks is $N-(z+1)=(N-1)(1-p)$. Total hits are $z^{2}$ in theory, but some banks have already failed in phase I and phase II. Generally, each of the $(N-1)(1-p)$ survival bank will suffer $k(k=0,1,2, \ldots \ldots \ldots, z)$ hits from the phase II defaulting banks with probability,

$$
P(k)=\left[\frac{z !}{(z-k) ! k !}\right] p_{k}(1-p)^{z-k}
$$

Each defaulting bank in phase II may bring each of their $z$ creditor banks about a shock as follows, 


$$
S(\text { III })=\frac{\min \left\{\theta, \frac{\min [\theta, f(\mathbf{1}-\theta)-\gamma]}{z}-\gamma\right\}}{z}
$$

Assuming one or more banks suffer $k_{c}$ times shock in phase III, the magnitude of the shock is $k_{c} S$ (III). The criterion for bank failure is $k_{c} S(\mathrm{III})>\gamma$.

\subsection{Liquidity shock}

Credit shock investigates only the loss of failed banks to its creditor banks, but not the impact on the external assets. Once a bank is in distress, liquidity shortage is the initial problem. The failed bank has to fire-sale assets, which will inevitably bring about the depression of asset prices in the market (Coval and Stafford, 2005; Mitchell et al., 2007; Nasir et al., 2020; Gai and Kapadia, 2010; Haldane and May 2011). Assume the value of illiquid assets is decreased by factor $q$, with $q=\exp (-\alpha x)$. Here $x$ denotes the number of failed banks to the number of total banks, that is, $N$. $\alpha$ measures the market's sensitivity to failures, with $\alpha \in[0,1]$ [5].

3.2.1 Failure in phase I. The impact of liquidity shock on the system in phase I is similar to credit shock, as shown in Section 3.1.1.

3.2.2 Failure in phase II. Unlike the credit shock, the effects of liquidity shock are transmitted to every bank in the financial network. That is to say, the failure of the first bank will reduce the external assets of all other banks by the factor $q$. Then, the amounts of phase II shock denoted as $S^{*}(I I)$ are as follows,

$$
S^{*}(I I)=\beta_{1}(1-\theta)
$$

Here $(1-\theta)$ measures the average of a bank's external assets if total assets are normalized to 1. From equation (3.5), the entire system crashes when,

$$
\beta_{1}(1-\theta)>\gamma
$$

By overlapping both credit and liquidity shocks, the criterion for phase II failure of $z$ banks is as follows,

$$
\beta_{1}(1-\theta)+\frac{\min [\theta, f(1-\theta)-\gamma]}{z}>\gamma
$$

3.2.3 Failure in phase III. If $z$ banks are in distress in phase II, the remaining $N-(z+1)$ banks have to suffer the third-round shock of $S^{*}(I I I)=\beta_{2}(1-\theta)$. With $\beta_{2}=1-\exp \left(-\alpha x_{2}\right)$, and $x_{2}=(1+z) / N$. The entire system crashes when $\beta_{2}(1-\theta)>\gamma$.

\section{Data and network topology}

\subsection{Data}

This paper uses the BankFocus database by Bureau van Dijk (BvD) and Fitch to obtain the financial statement data of Chinese banks, including loans and advances to banks, deposits from banks and shareholders' equity. Seven state-owned banks, 12 joint-stock banks, 95 city commercial banks, 45 rural commercial banks, 40 foreign banks, financial leasing and private banks are included in the data set. The "Loans and advances to banks" is used as the asset item, and "Deposits from banks" is used as the liability item.

\subsection{Bilateral exposure matrix}

It is necessary to build a debt credit network to investigate the interconnects among financial institutions and obtain the degree of risk exposure. Assume there are $N(N>2)$ financial 
IJOEM

17,3

institutions in the network, and the probability of interbank lending by each institution is subject to independently identically distribution (Kanno, 2015; Paltalidis et al., 2015). Hence, the lending relationship in the interbank market can be represented by the $N \times N$ matrix as follows.

$$
X=\left[\begin{array}{c|ccccc}
a_{1} & x_{11} & \cdots & x_{1 j} & \cdots & x_{1 N} \\
\vdots & \vdots & \ddots & \vdots & \ddots & \vdots \\
a_{i} & x_{i 1} & \cdots & x_{i j} & \cdots & x_{i N} \\
\vdots & \vdots & \ddots & \vdots & \ddots & \vdots \\
a_{N} & x_{N 1} & \cdots & x_{N j} & \cdots & x_{N N} \\
\Sigma_{i} & l_{1} & \cdots & l_{i} & \cdots & l_{N}
\end{array}\right]
$$

where $x_{i j}$ denotes outstanding loans from the institution $i$ to the institution $j$, and at the same time also indicates the borrowings of bank $j$ from bank $i$. The information entropy theory is used to select a distribution for the lending entry data $x_{i, j}$. Such that $a_{i}=\sum_{j=1}^{N} x_{i j}, l_{i}=\sum_{i=1}^{N} x_{i j}, a_{i}$ indicates the total amount of funds lent by financial institution $i$ to other institutions in a given year, $l_{i}$ indicates the total amount of funds financial institution $i$ borrowed from other financial institutions in a given year. The issue of entropy maximizing and interbank assets normalization can be denoted as follows:

$$
\begin{gathered}
\min \sum_{i=1}^{N} \sum_{j=1}^{N} x_{i j} \operatorname{In} x_{i j} \\
\text { s.t. } \quad \sum_{j=1}^{N} x_{i j}=a_{i}, \sum_{i} a_{i}=1 \\
\sum_{i=1}^{N} x_{i j}=l_{j}, \sum_{j} l_{j}=1 \\
x_{i j}>0
\end{gathered}
$$

$a_{i}$ and $l_{i}$ subject to the marginal distributions $f\left(a_{i}\right)$ and $f\left(l_{i}\right)$, while the matrix $X$ subject to the joint probability distribution $f\left(a_{i}, l_{i}\right)$. Assuming that $f\left(a_{i}\right)$ and $f\left(l_{i}\right)$ are independently distributed, the matrix is standardized, thus $\sum_{i} a_{i}=\sum_{i} l_{i}=1$, a new matrix $X$ is as follows,

$$
X^{\prime}=\left[\begin{array}{c|ccccc}
a_{1}^{\prime} & x_{11}^{\prime} & \cdots & x_{1 j}^{\prime} & \cdots & x_{1 N}^{\prime} \\
\vdots & \vdots & \ddots & \vdots & \ddots & \vdots \\
a_{i}^{\prime} & x_{i 1}^{\prime} & \cdots & x_{i j}^{\prime} & \cdots & x_{i N}^{\prime} \\
\vdots & \vdots & \ddots & \vdots & \ddots & \vdots \\
a_{N}^{\prime} & x_{N 1}^{\prime} & \cdots & x_{N j}^{\prime} & \cdots & x_{N N}^{\prime} \\
\Sigma_{i} & l_{1}^{\prime} & \cdots & l_{i}^{\prime} & \cdots & l_{N}^{\prime}
\end{array}\right] \text { with } x_{i j}^{\prime}= \begin{cases}0 & \forall i=j \\
a_{i} \times l_{i} & i \neq j\end{cases}
$$

By maximizing the information entropy, the optimization problem is solved by the RAS algorithm, which is proposed by Censor et al. (1998), 


$$
\begin{gathered}
\min \sum_{i=1}^{N} \sum_{j=1}^{N} x_{i j} \ln \left(\frac{x_{i j}}{x_{i j}^{0}}\right) \\
\text { s.t. } \sum_{j=1}^{N} x_{i j}=a_{i}, \sum_{i} a_{i}=1 \\
\sum_{i=1}^{N} x_{i j}=l_{j}, \sum_{j} l_{j}=1
\end{gathered}
$$

Risk contagion in Chinese banking network

Given an initial value $L_{0}$, the RAS algorithm should follow three steps to solve the matrix $X^{\prime}$. (Censor et al, 1998; Kanno, 2015). Step 1: the row scaling: calculating of $\rho_{i j}^{k} x_{i j}^{k}$ to replace $x_{i j}^{k}$, with $\rho_{i j}^{k}=a_{i} / \sum_{\forall j \mid} x_{i j}^{\prime}>0 x_{i j}^{k}$. Step 2: the column scaling: calculating $\sigma_{i j}^{k} x_{i j}^{k}$ to replace $x_{i j}^{k}$, with $\sigma_{i j}^{k}=l_{i} / \sum_{\forall i \mid x_{i j}^{\prime}>0} x_{i j^{\prime}}^{k}$ Step 3: $k=k+1$, and return to step 1. Then, the amount of interbank market loans and deposits of each institution, denoted as $a_{i}$ and $l_{i}$, are obtained.

\subsection{Chinese interbank network analysis}

The bilateral exposure of Chinese financial institutions is illustrated in Figure 3. The width of an edge denotes its interbank exposure size in 2019, and different color represents different bank type. The nodes in the graph represents Chinese banks, and the node size depends on the number of its connections. The bigger the size of the node, the larger the amount of the bank's borrowing. The link between the two circles represents the lending relationship between the two banks. The thicker the connection, the higher the volume of the transaction, and the closer relationship between two banks. The state-owned banks (SOBs) and policy banks in the middle have the largest circle and the thickest connecting lines, indicating that they have the most significant interbank transactions and the closest correlation with other banks. Next, there exists also large number of connections between SOBs and joint stock banks (JSBs). It indicates that once an SOB is in distress, JSBs will suffer huge asset impairment loss with high probability. Therefore, risk contagion caused by SOBs deserves more attention.

The number of city commercial banks (CCBs) is the largest, but they have not shown particular importance in the financial system. CCBs have the most interconnections with JSBs, which indicates the tight correlation between the two banks. The relationship among CCBs, SOBs and policy banks is relatively strong. However, CCBs have few transactions with rural commercial banks (RCBs) and foreign banks. Restricted by the trading rules and regulations, foreign banks are not active participants in the Chinese interbank market. As shown in Figure 3, foreign banks only have transactions with big banks, namely, SOBs and JSBs, but have few transactions with small and medium banks, namely, CCBs and RCBs [6].

\subsection{Topology and interconnectedness of the interbank network}

4.4.1 Degree centrality. As shown in Figure 3, the network can be represented by a matrix, $D=(N, A)$. Where $N$ denotes a set of all nodes, $A$ represents a set of all connections and elements in matrix $A$, that is, $a_{i j}$, represent the existence of a lending relationship between node $i$ and node $j$. If there is a lending relationship $a_{i j}=1$ or $a_{i j}=0$. If $N(i)$ is used to represent all the connections of node $i$, the degree of centrality $d_{i}$ can be represented $d(i)=\sum_{j \in N(i)} a_{i j}$. We can calculate the in-degree of the network node, that is, the number of funds that each bank has borrowed from other banks. And out-degree measures the number 


\section{IJOEM \\ 17,3}

898

Figure 3.

Chinese interbank network graph (2019)

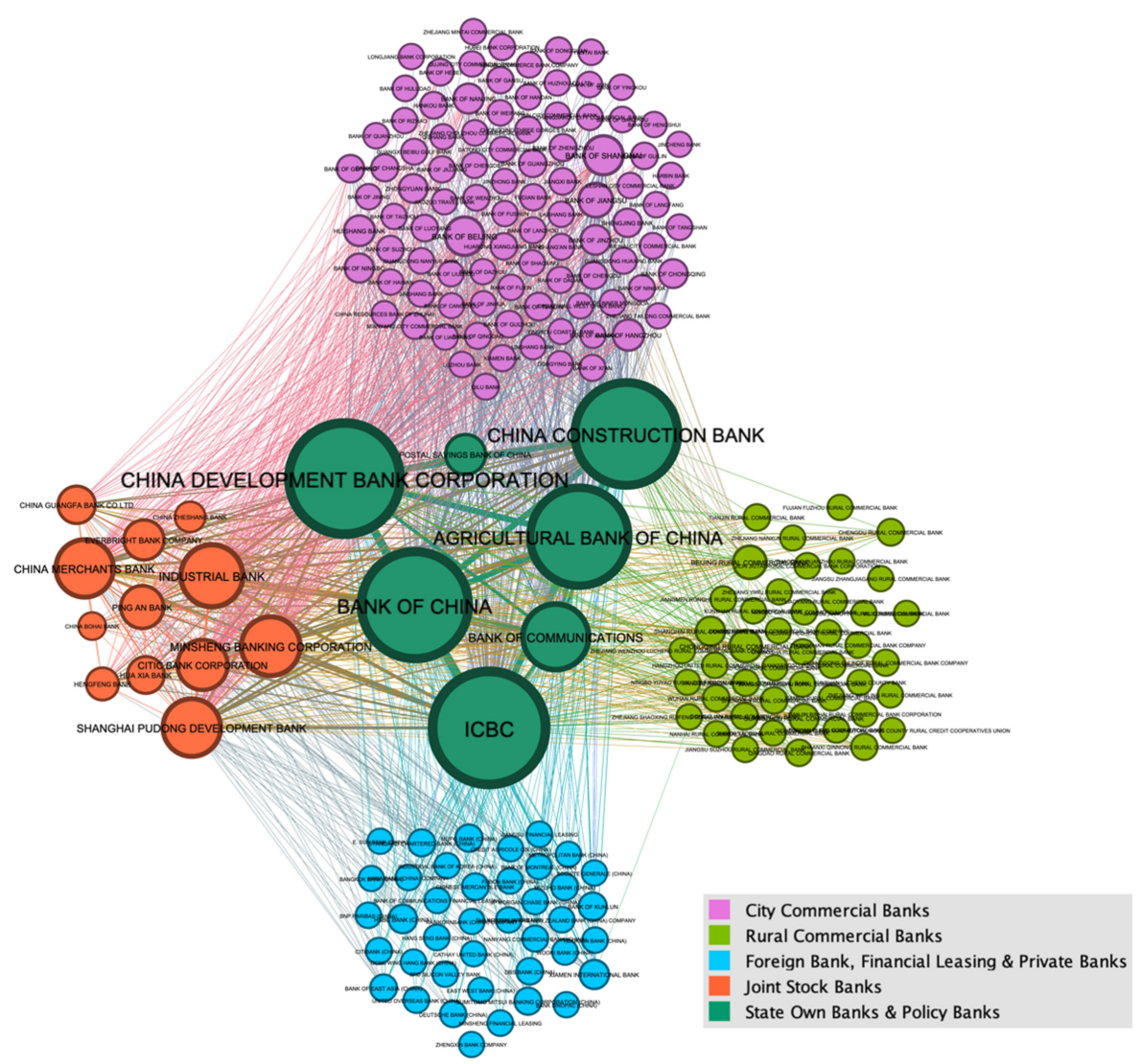

of funds that each bank has to lend to other banks. If $d_{i}^{-}$indicates node exit, $d_{i}^{+}$indicates node entry. They can be represented as:

$$
d_{i}^{-}=\sum_{j \in N^{-}(i)} a_{i j} \quad \text { and } \quad d_{i}^{+}=\sum_{j \in N^{+}(i)} a_{i j}
$$

4.4.2 Closeness centrality. Closeness centrality calculates the sum of the distance of a given node to all other nodes in the financial network. The smaller the closeness centrality, the shorter path from this point to other points, which means this node is closer to others. A high closeness measure indicates the node bank is closest to other nodes in the network and is spatially reflected in the central location. If $d\left(b_{i}, b_{j}\right)$ is used as the number of the shortest edge between bank $i$ and bank $j$, the closeness centrality can be represented as follows,

$$
C\left(b_{i}\right)=n / \sum_{j=1}^{n} d\left(b_{i}, b_{j}\right)
$$

Given the orientation of the financial network, in-closeness centrality and out-closeness centrality can be calculated. In-closeness indicates how easy it is for a bank to borrow funds within the financial network. The higher the in-closeness centrality, the easier it is to borrow 
funds. Out-closeness centrality indicates how easy it is for a bank to lend funds within the financial network. The closer the centrality, the easier it is for the institution to lend funds to other institutions. Thus, in-closeness centrality reflects the integration force of the bank, while out-closeness centrality reflects the radiation force of the bank within the network.

4.4.3 Betweenness centrality. Betweenness centrality calculates the number of shortest paths through a node. If $p_{j k}$ represents the number of the shortest paths between node $j$ and $k$, $p_{j k}(i)$ represents the number of shortest paths passing through node $i$ between node $j$ and node $k$. Betweenness centrality is the number of times a financial institution acts as a bridge between two other institutions. The higher the number of times it acts as an intermediary, the higher is the degree of betweenness centrality. After the normalization, the betweenness centrality can be represented as follows:

$$
B(i)=\sum_{j<k ; i \notin\{k, j\}} p_{j k}(i) / p_{j k}
$$

4.4.4 PageRank centrality. PageRank centrality comes from Google's PageRank algorithm. In order to ensure the integrity of information, the weight of internode connections is the amount of risk exposure of financial institutions that needs to be considered in the interbank network. By introducing the inverse of the eigenvalue less than the maximum $A D^{-1}$, denoted as $\alpha$, the centrality can be expressed as:

$$
x=\left(I-\alpha A D^{-1}\right)^{-1}=D \cdot(D-\alpha A)^{-1}
$$

4.4.5 Distribution of centralities. The statistical distribution of centrality is illustrated in Figure 4. On the other hand, China's interbank market has shown a noticeable clustering effect. Taking the degree centrality as an example, the higher the degree, the more institutions the bank is connected, the more critical and irreplaceable the bank is in the financial network. The lending volume of the top 18 banks accounts for $31.99 \%$ of the total interbank loans. The conclusions of betweenness and PageRank centrality also show a similar phenomenon. The value of the top 16 financial institutions accounts for $81.44 \%$ of total betweenness centrality, while the value of the
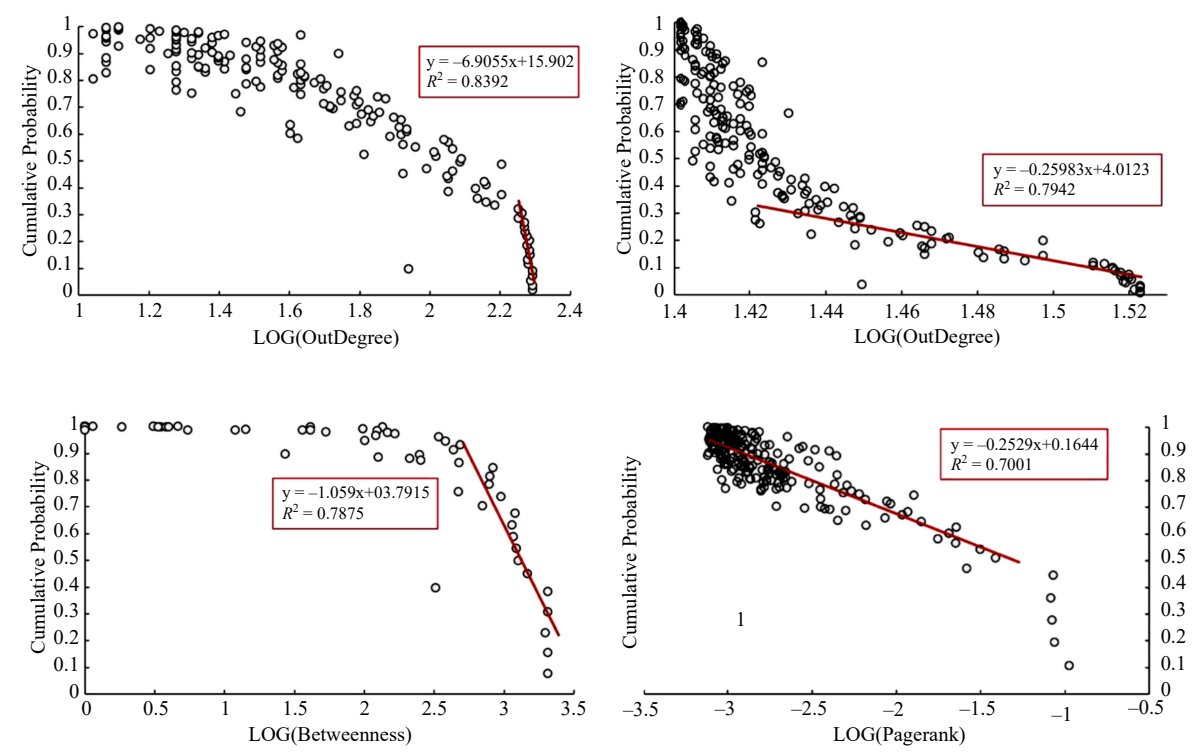

Figure 4.

Log-log plots of the degree distribution (in 2019): upper left panel: out-degree of centrality, upper right panel: out closeness centrality, lower left panel: betweenness centrality, lower right panel: PageRank centrality 
IJOEM

17,3

900 top 6 banks accounts for $51.04 \%$ of the total PageRank centrality. It shows that there exist clustering effects of large banks in China's financial network. It is of great significance to pay attention to systemically important banks, especially SOBs, to investigate the contagion effects of systemic risk. Among these important institutions, the ICBC ranks the first in the degree of centrality, closeness centrality, betweenness centrality and PageRank centrality, which indicates that ICBC plays a leading role in the financial market. This paper investigates the impact of credit shock or liquidity shock caused by the bankruptcy of ICBC in the financial network.

\section{Contagion effects of shocks}

In this chapter, the balance sheet data of banks are used to investigate how and to what extent the risk propagates within the financial network. The first group of simulation investigates the knock-on effects of credit shock triggered by the debt default in the interbank market, as shown in Section 5.1. The second group of simulation investigated the knock-on effects of liquidity effects, which is featured by "fire-sale" of bank assets, as shown in Section 5.2. The third group of simulations investigates the contagion effects of combined shocks, which mean the same effect of both credit shock and liquidity shock, as shown in Section 5.3.

\subsection{Contagion effects of credit shocks}

In this section, the contagion effects and propagation process are presented. We make four round shocks on the financial network. The results illustrate the number of banks in distress and the loss of bank equity in each round to demonstrate the effect of a credit shock.

5.1.1 Number of banks in distress. Under the scenario of credit shock, banks can rollover the assets. Therefore, banks have enough time to sell the assets at fair market value. In other words, no fire-sale occurs. If a typical bank is assumed to be in distress, all of its debts are default and the loss will be transmitted to all its creditor banks. The results indicate that the credit risk of only five giant banks could bring about the risk contagion within China's banking network, as shown in Table 2. When the default loss rate, denoted as delta, was higher than 0.77, the default of ICBC or CCB could have caused SPD Silicon Valley Bank (SSVB) to be in distress. The bankruptcy of the BOC could have caused the collapse of SSVB if the default loss rate was between 0.61 and 0.9 , and the failure of both SSVB and Woori Bank (WB) if the default loss rate was higher than 0.9. This result indicates that WB and SSVB, with only $\$ 428$ and $\$ 147$ in total equity, respectively, were vulnerable to credit shocks. But the financial system as a whole is robust to credit shock [7]. This result is in line with the studies by Lixin Sun (2019) and Chen et al. (2020a, b), which argue that due to the strict supervision and high required reserve ratio, the credit shock has little impact on the Chinese financial system. It could be attributed to the relatively high depositreserve ratio of commercial banks, which the China Banking and Insurance Regulatory Commission (CBIRC) stipulates [8].

5.1.2 Impairment loss of bank equity. The bankruptcy of a typically systemic important bank could bring about the credit shock to its creditor banks and result in the loss of equity to the

\begin{tabular}{lll}
\hline Initial bankruptcy & Default loss rate & Banks in distress \\
\hline ICBC & delta $\geq 0.77$ & SSVB \\
CCB & delta $\geq 0.77$ & SSVB \\
ABC & delta $\geq 0.84$ & SSVB \\
BOC & $0.9>$ delta $\geq 0.61$ & SSVB \\
& delta $\geq 0.9$ & SSVB, WB \\
CDB & $0.84>$ delta $\geq 0.58$ & SSVB \\
& delta $\geq 0.84$ & SSVB, WB
\end{tabular}

\section{Table 2.}

Risk contagion in China's banking system under a credit shock 
entire financial system. After the first-round shock, with the increase of default loss rate, the asset impairment loss of the banking system increases linearly. Under the extreme pressure scenario, that is, the default loss rate equals one, the failure of ICBC would result in a total loss of 0.38 million USD to the entire banking system. After the second-round shock, when the default loss rate is higher than 0.77, the asset impairment loss begins to arise in the financial system. With default loss rate changing from 0.77 to 0.8 , asset impairment loss increased sharply from 0 to 88.43 million USD. With the default loss rate varies from 0.8 to 1 , the impairment loss increased from 88.43 to 106.85 million USD. Affected by the bankruptcy of ICBC, SSVB, which went bankrupt in the first round, caused asset impairment in the second round but did not lead to the failure of other banks. Therefore, there is no systemic risk passed on, and the third and fourth round shocks could not lead to asset impairment loss, as shown in Figure 5.

\subsection{Contagion effects of liquidity shocks}

This section presents the contagion effects of liquidity shocks on the banking system. In this section, a typically systemic important bank, that is, ICBC, is assumed to be in distress. Banks can rollover the assets, which means no fire-sale occurs. Once a bank is in distress, all the debt is default. The results illustrate the number of banks in distress and the loss of bank equity in four rounds. We illustrate the contagion effect when the rollover rate equals $0.2,0.5$ and 0.8 , respectively, in the following sections.

5.2.1 Number of banks in distress. Once ICBC is in distress, the loss will be transmitted to its creditor banks. The number of banks in distress in each round varies with the discount rate and the rollover ratio. We illustrate the results when the rollover ratio equals $0.2,0.5$ and 0.8 , respectively, as shown in Figure $6-8$. The discount rate and the rollover ratio have shown opposite effects. The higher the discount rate, the greater the loss of assets and the easier it is for banks to be in distress. On the contrary, the larger the rollover ratio, the longer the asset
Risk contagion in Chinese banking network

901
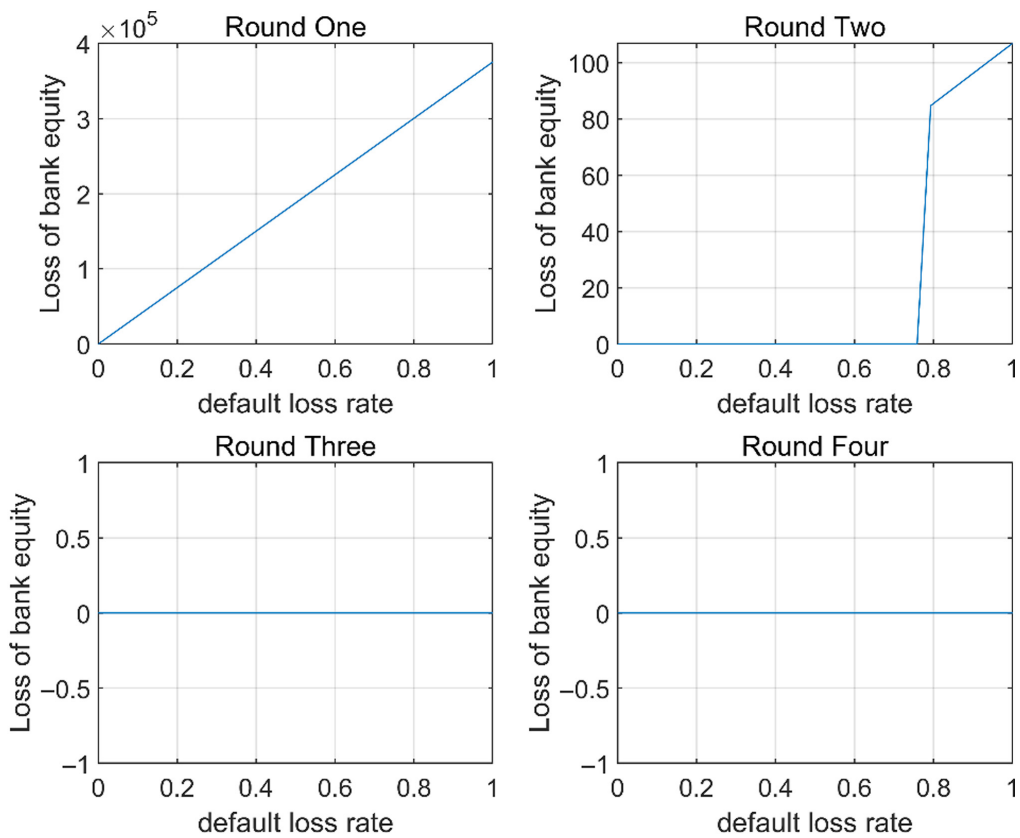

Figure 5.

Loss of bank equity in different default loss rates 
IJOEM

17,3

\section{2}

Figure 6.

Number of banks in distress if rollover ratio $=0.2$
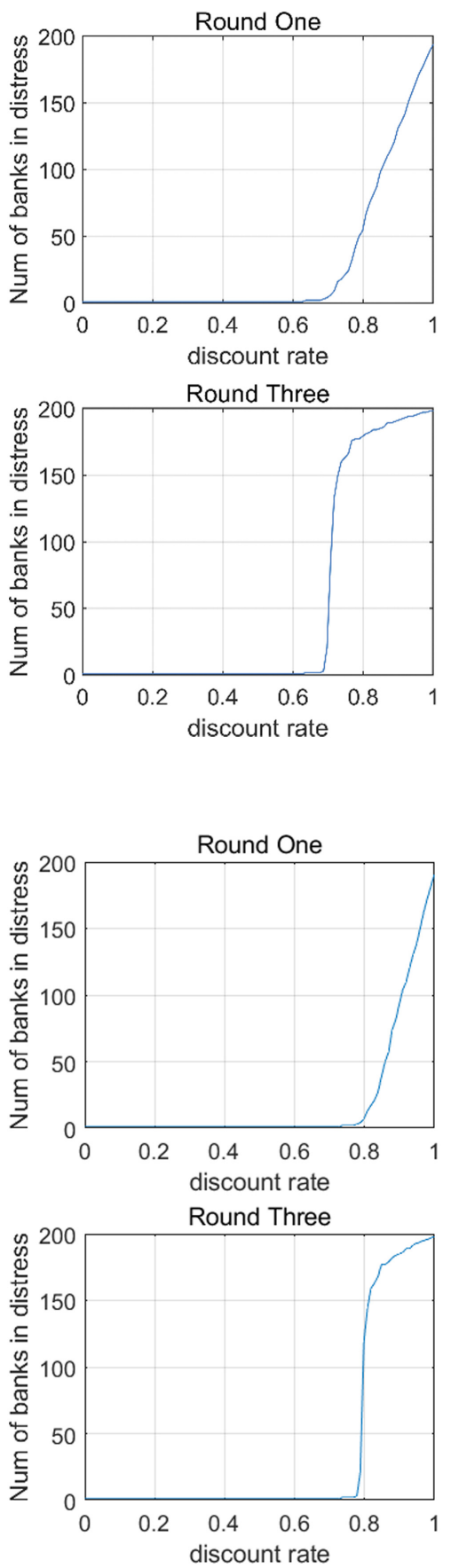
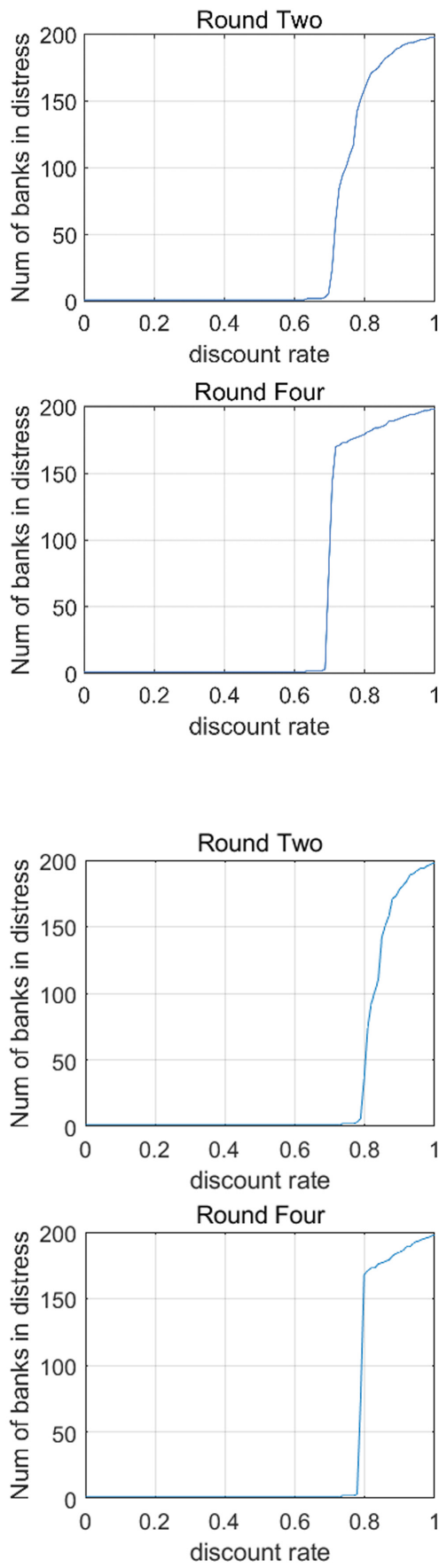

Figure 7.

Number of banks in distress if rollover ratio $=0.5$ 

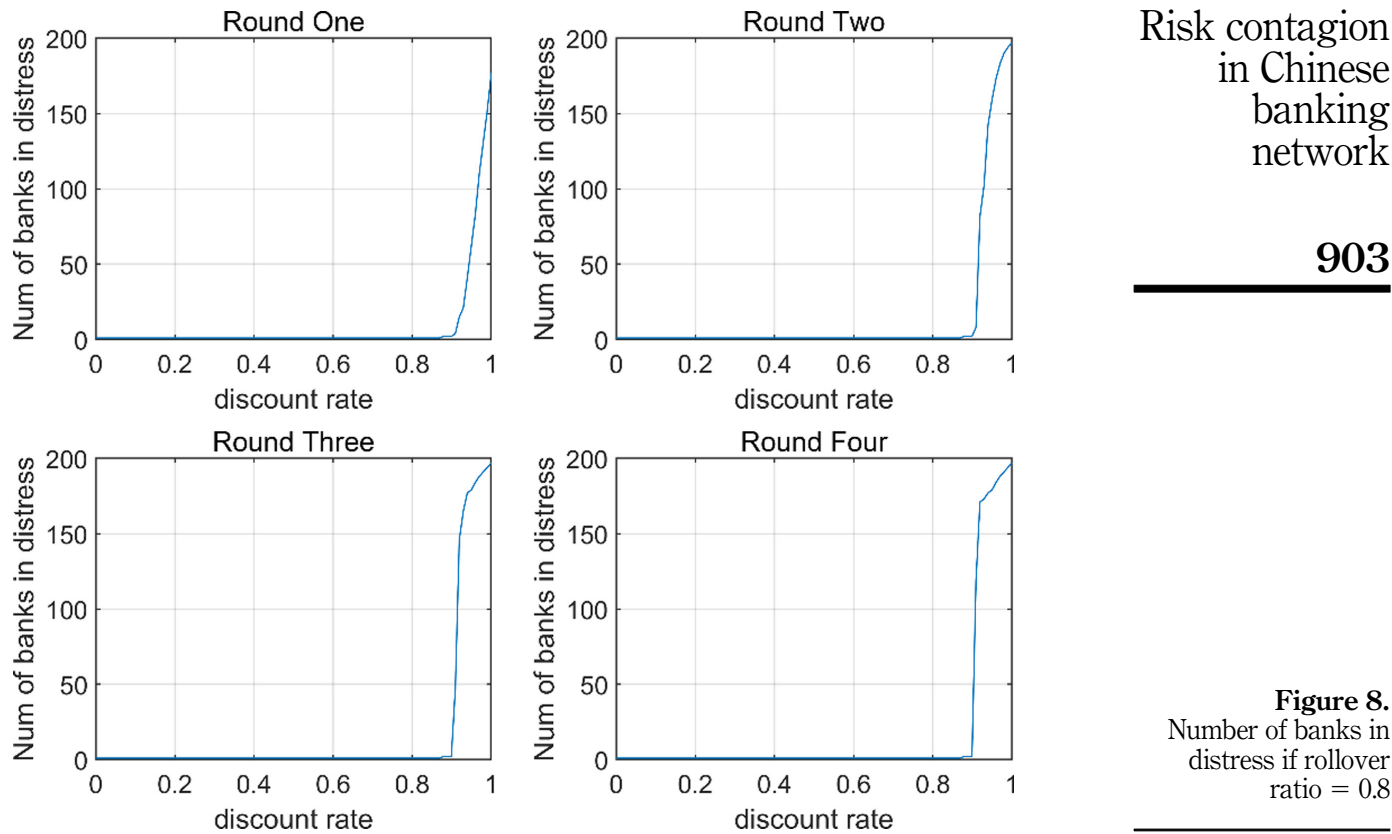

Figure 8.

Number of banks in distress if rollover ratio $=0.8$

sales time, the fire-sales may be avoided and therefore a lower probability for large-scale bankruptcy in the banking system. In other words, if the rollover ratio is high, the systemic risk occurs only when the discount rate is high. If the rollover ratio equals 0.2 , the bank failure begins to occur when the discount rate is 0.65 . If the rollover ratio is 0.5 , the systemic risk contagion begins to arise when the discount rate is 0.75 . Once the rollover ratio reaches 0.8 , the risk contagion begins to arise when the discount rate is as high as 0.85 .

Take the case of a rollover ratio of 0.2 , as shown in Figure 6. When the discount rate increases to 0.65 , the contagion begins to occur. If the rollover rate is between 0.65 and 0.7 , the number of banks in distress increases slightly with the discount rate. When the rollover rate is higher than 0.7 , the number of banks in distress rises linearly with the discount rate in the first round. It has shown an upward trend of banks in distress exponentially in the second and third rounds. With the increase of discount rate, the number of bankruptcies in the fourth round rose rapidly at first and then rose gently. If the discount rate is 0.8 , the total number of banks in distress in the first, second, third and fourth rounds is $67,165,181$ and 181, respectively. When the discount rate reaches 0.9 , the total number of the first, second, third and fourth rounds of banks in distress is 136, 192, 192 and 192, respectively. It shows that when the discount rate reaches 0.8 , after the second round, the market turns toward stability. To sum up, once banks are forced to fire-sale assets, when the discount rate is greater than 0.6, the financial system's stability will be threatened. When the risk propagates to the third round, the entire financial network will suffer from systemic risk contagion. When the discount rate is 0.7 , the bankrupt of ICBC will result in the collapse of the other five banks in the first round, namely Industrial Bank Co Ltd, Bank of Jiangsu Co Ltd, Bank of Hangzhou, Bank of Jinzhou and Mianyang City Commercial Bank. These banks are most closely related to ICBC, with a large number of interbank transactions. Industrial Bank used to be known as the "king of the interbank market" in the banking sector. Although the scale of the interbank business has declined in recent years, its position in the interbank system cannot be ignored. In addition, the equity of the other four city commercial 
IJOEM 17,3

\section{4}

banks is low, which makes them vulnerable to the liquidity shock. Among the 18 banks that failed in the second round, four JCBs are more representative, namely Shanghai Pudong Development Bank, Minsheng Bank, Ping-An Bank and Huaxia Bank. It shows that although JCBs hold more equity than CCBs, the relatively higher interbank transactions make them more vulnerable to the liquidity shocks within the interbank network.

5.2.2 Impairment loss of bank equity. In this section, we represent the loss of bank equity at different discount rates when the rollover ratios equal $0.2,0.5$ and 0.8 , respectively, as shown in Figures 9-11. In the first round, the impairment asset loss increases exponentially with the discount rate. In the second, third and fourth rounds, the curve shapes are similar. They all rise to the peak value and then decline. It is simply because, with a high discount rate, the firstround shock has caused most of the impairment loss, and the subsequent rounds only caused loss of remaining assets. The volume of total impairment loss in each round decreases gradually. Similar to the number of banks in distress, if the rollover ratio are 0.2, 0.5 and 0.8, the impairment losses begin to occur when the corresponding discount rates are $0.65,0.75$ and 0.85 . The higher the rollover ratio, the higher the value of discount rate. Take the case of the rollover ratio of 0.2 , as shown in Figure 9. if the discount rate is less than 0.65 , the impairment loss occurs only in the first round. There is no impairment loss in the second, third and fourth rounds. Since the liquidity shock does not result in any failures in the first round, it does not bring about the risk contagion within the banking network. When the discount rate is equal to 0.7, the impairment losses are 1.3 trillion, 0.35 trillion, 0.7 trillion, 0.94 trillion, in the first, second, third and fourth rounds, respectively. When the discount rate is equal to 0.8 , the impairment loses are 2.3 trillion, 2.4 trillion, 43 billion, 0.62 billion in the first, second, third and fourth rounds, respectively. At this time, the first two rounds of shocks have a greater impact on the impairment loss of bank equity, and the impact of the latter two rounds begins to weaken. When the discount rate is equal to 0.9 , the impairment losses are 5.2 trillion, 0.43
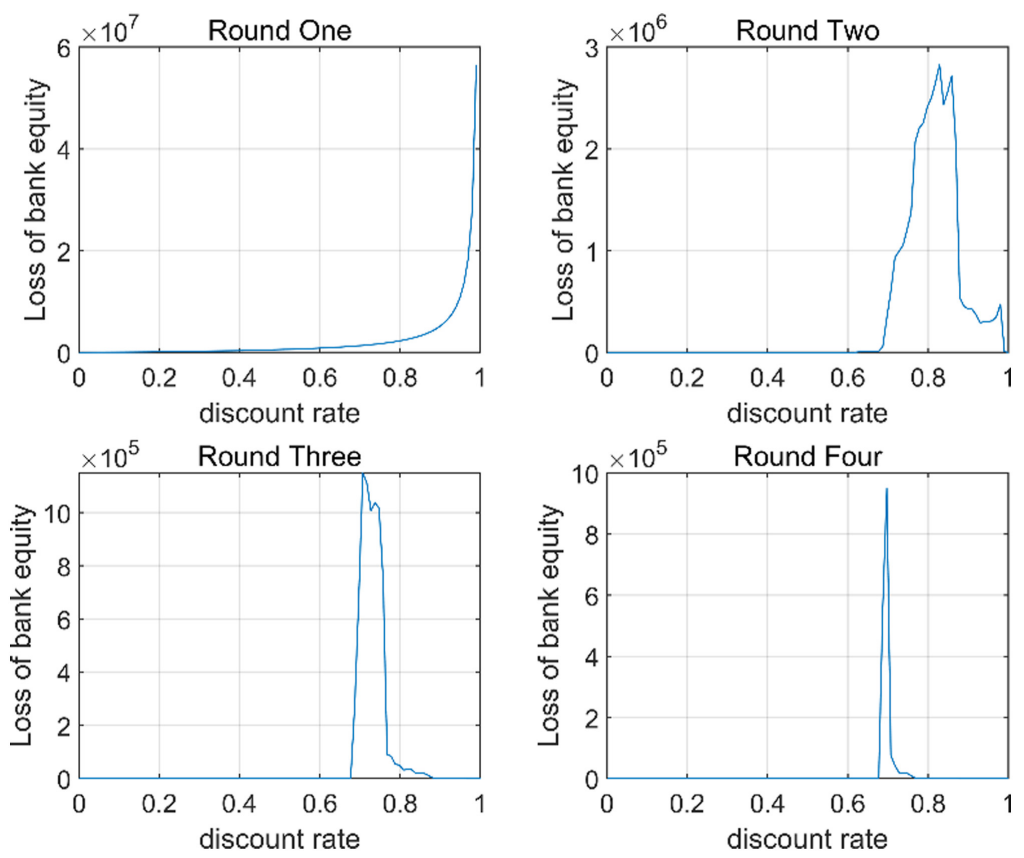

Figure 9.

Loss of bank equity if rollover ratio $=0.2$ 

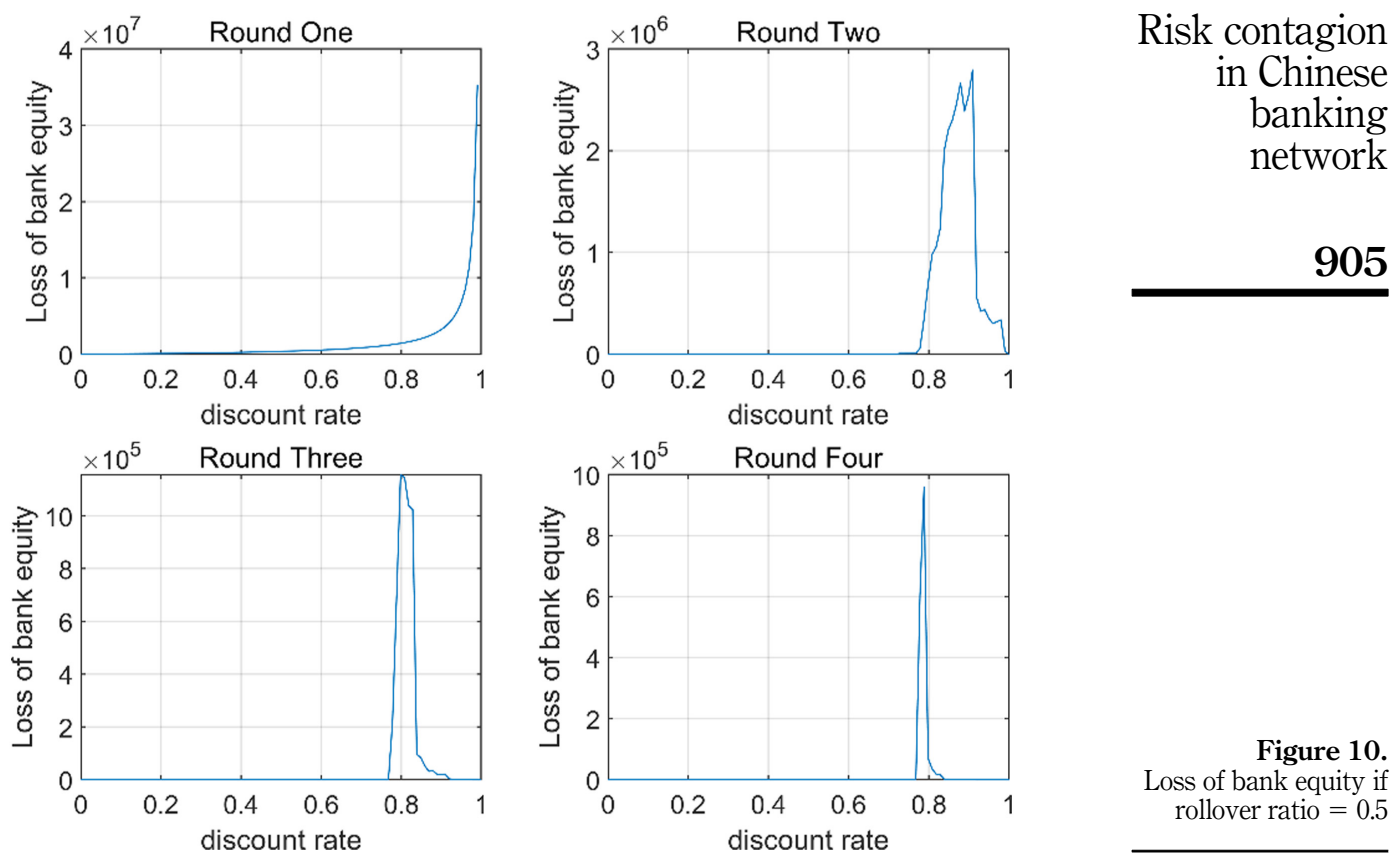

905

Figure 10.

Loss of bank equity if rollover ratio $=0.5$
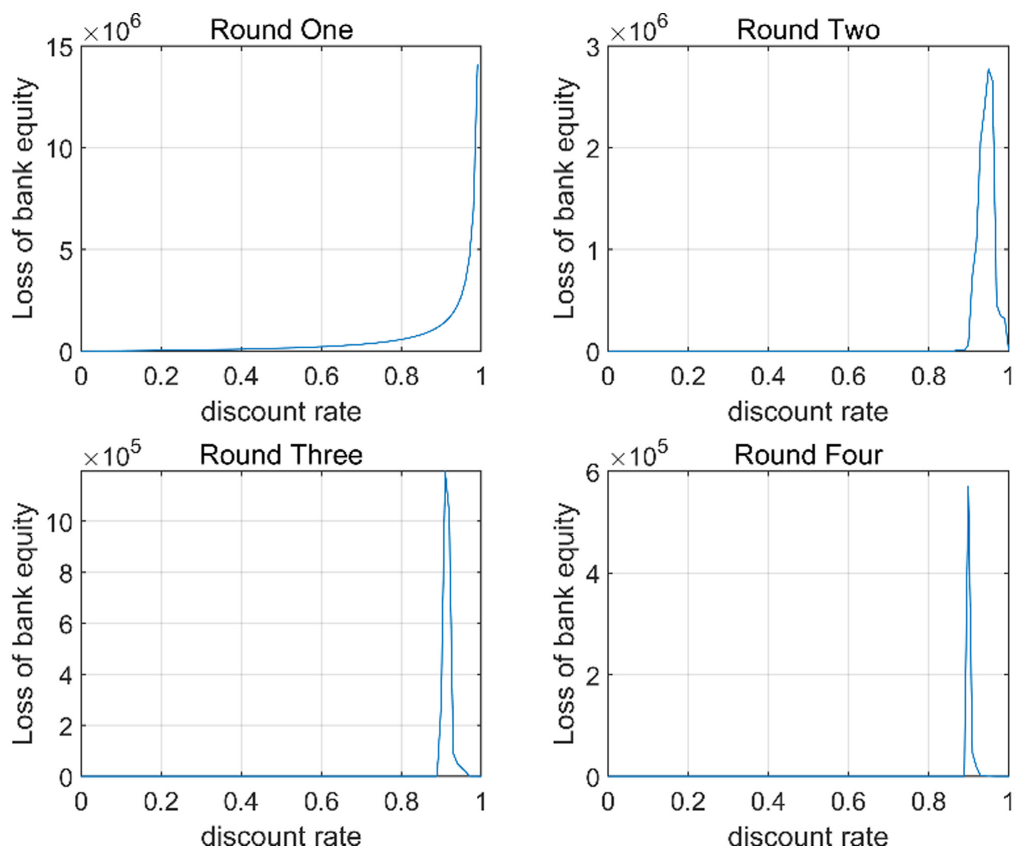

Figure 11.

Loss of bank equity if rollover ratio $=0.8$ 
IJOEM 17,3

906

trillion, 198 million, 0 in the first, second, third and fourth rounds, respectively. Due to the high discount rate, most of the banks are in distress in the first round, and the risk is not propagated to the following rounds.

\subsection{Contagion effects of credit shocks plus liquidity shocks}

In this section, we present the contagion effects of credit shocks plus liquidity shocks. The number of banks in distress and the loss of bank equity are shown when the two shocks occur simultaneously.

5.3.1 Number of banks in distress. We show the number of banks in distress if the credit shock and the liquid shock occur simultaneously. The rollover ratio is set to be $0.2,0.5$ and 0.8 , respectively. The default loss rate is between 0 and 1 , and the discount rate moves between 0.5 and 0.95 [9]. In the first and second rounds of shocks, risks propagate quickly through the financial network. There is little difference between the shape of the third and the fourth rounds, which indicates that the system tends to be stable after the second-round shock. When the discount rate is low, the number of banks in distress does not increase significantly with the default loss rate. However, if the discount rate is large, even if the default loss rate is low, there will be a high number of bank distress. This result shows that, compared with the default loss rate, the impact of asset discount rate on the number of failures is more significant.

When rollover equals 0.2 and discount rate is 0.8 , risk contagion appears, as shown in Figure 12. When the discount rate is between 0.8 and 0.9 , the number of bank failures is determined by both the default loss rate and discount rate. Once the discount rate reaches 0.95 , the number of banks in distress after the first round is about 170, and the risk propagates in the whole network after the second round. In this case, the default loss rate has little effect on the result. If the rollover ratio equals 0.5 , the risk begins to propagate when the discount rate is 0.85 , as shown in Figure 13. Furthermore, we illustrated the impact of the default loss rate on the number of bank failures when the discount rate is 0.87 . The number of banks in distress caused by the first-round shock is relatively small, and the number of banks in distress increases significantly after the second round. When the default loss rate is greater than 0.6 , there is little difference between the results of the third round and the fourth round, which indicates that the system is stable after the third round. On the other hand, when the default loss rate is less than 0.6 , the fourth-round shock will result in additional bank failures. If the rollover ratio equals 0.8 , as shown in Figure 14, only when the discount rate exceeds 0.9, risk contagion arises. In the
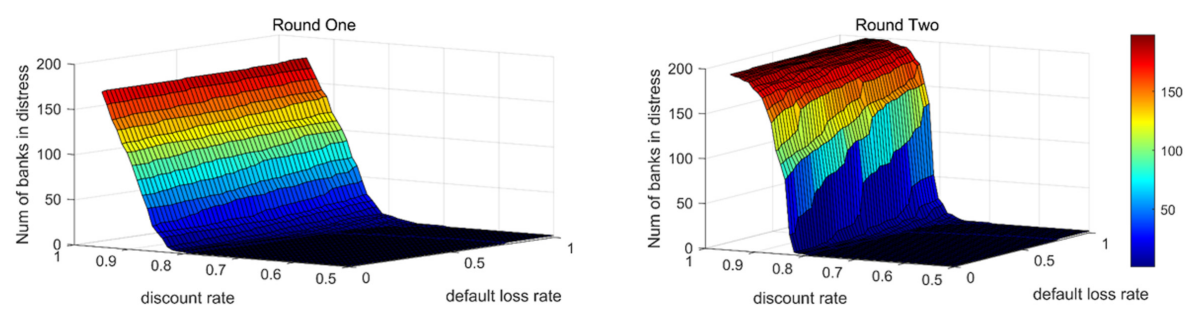

Figure 12.

Number of banks in distress if rollover ratio $=0.2$
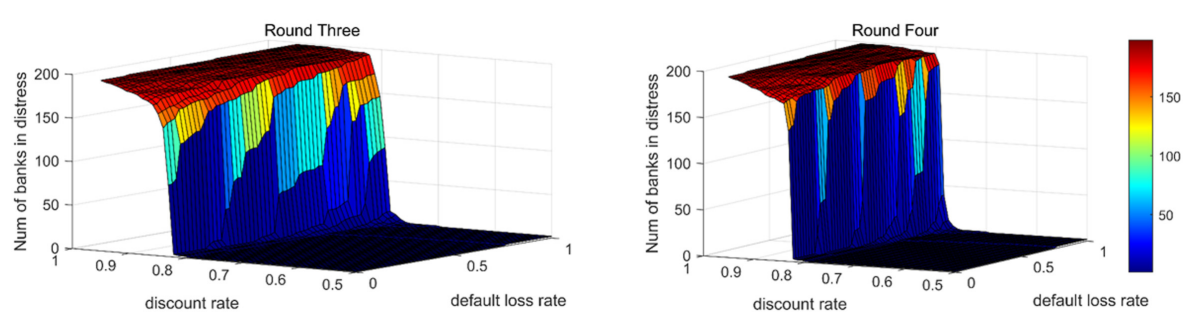

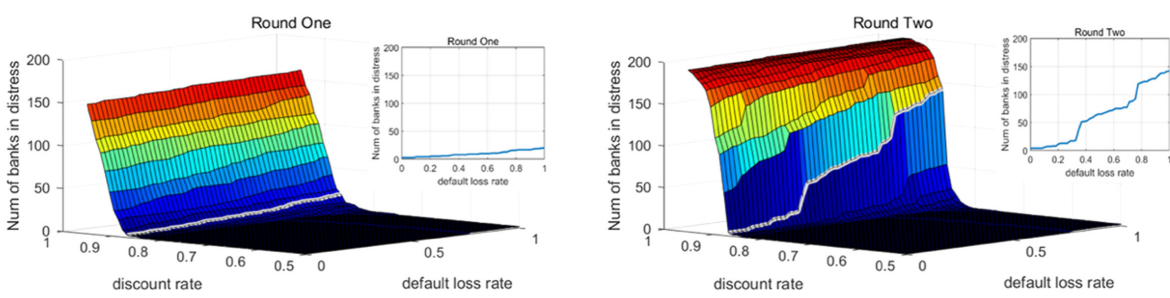

Risk contagion in Chinese banking network

907
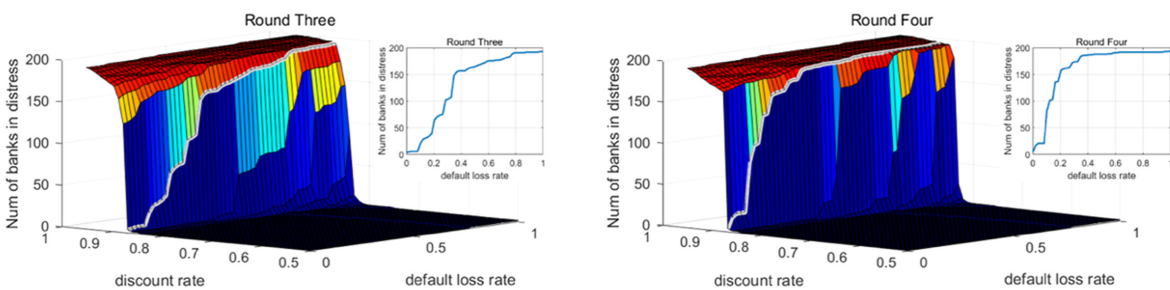

Figure 13.

Number of banks in distress if rollover ratio $=0.5$
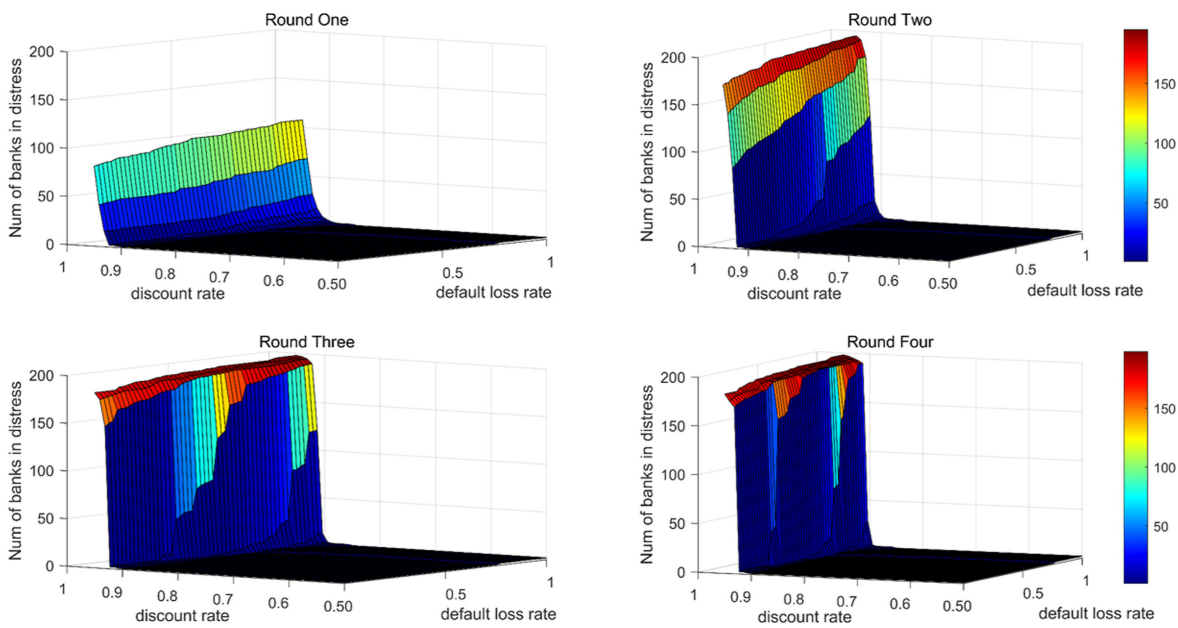

Figure 14.

Number of banks in distress if rollover ratio $=0.8$

extreme case of discount rate equals 0.95 and the default loss rate close to one, all banks in the whole system will be in distress after four rounds. This result indicates that when the rollover rate is high enough, the system is relatively robust to the shock.

5.3.2 Impairment asset loss of bank equity. This section illustrates the asset impairment loss if the credit shock and the liquid shock occur simultaneously. The rollover ratio is set to be $0.2,0.5$ and 0.8 , respectively. The asset impairment loss increases with the discount rate and default loss rate in the first round. And the impact of the discount rate is more significant than that of the default loss rate. It shows that the discount rate has a greater impact on risk contagion than the default loss rate in the first round. The total volume of asset impairment loss increases with the discount rate initially. When it reaches the peak value, the loss begins to decrease. Because when the discount rate is very high, the first round of shocks can cause most of the asset losses in the network, and most of the banks are already in distress. Only a few banks are affected in the following three rounds. 
IJOEM

17,3

\section{8}

Figure 15.

Loss of bank equity if rollover ratio $=0.2$

Figure 16.

Loss of bank equity if rollover ratio $=0.5$
As shown in Figure 15, if the rollover ratio equals 0.2, the asset impairment loss begins to arise when the discount rate is 0.8 . The total volume of loss increases to the peak value and then declines with the discount rate. The amount of impairment loss reaches the peak value when the discount rate equals 0.87 in the second round. In the third and fourth rounds, the impairment loss hits the peak value when the discount rates reach 0.84 and 0.82 , respectively. As shown in Figure 16 , when the rollover ratio equals 0.5 , the risk begins to propagate when the discount rate reaches 0.85 .

Similarly, the impact of the default loss rate on the asset impairment when the discount rate is 0.87 is observed, as shown in Figure 7 . In the first round, asset impairment loss increases linearly with the default loss rate. Then the loss has shown a ladder-like rise in the second round. In the third round, the loss rises to the peak value when the default loss
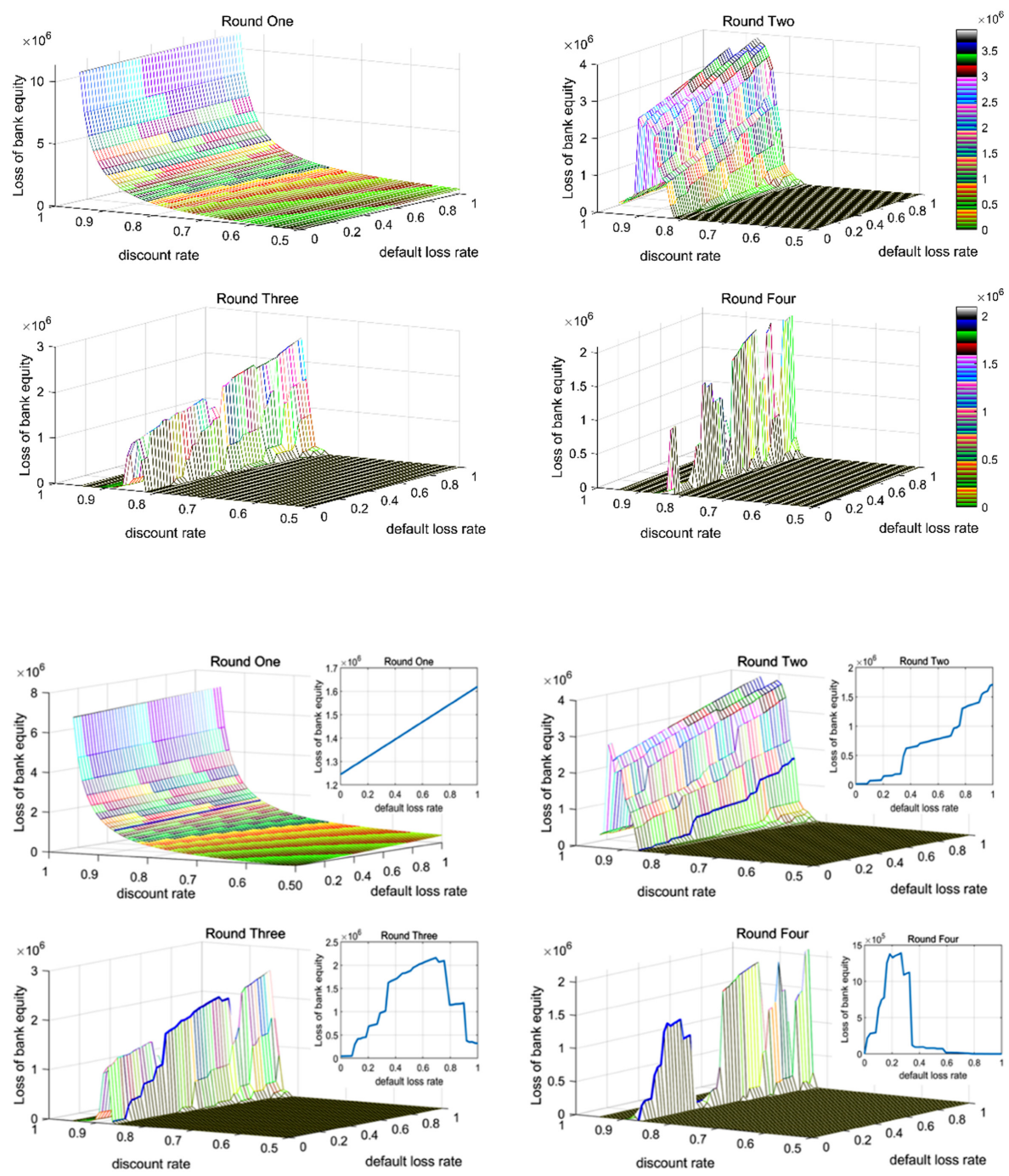
rate equals 0.7 , and then declines. In the fourth round, the asset impairment loss increases rapidly to the peak value when the default loss rate equals 0.3 and decreases quickly. The results indicate that if the discount rate is lower than 0.4 , the speed of risk contagion is slow, and the impairment loss is mainly concentrated in the fourth round. If the discount rate is higher than 0.4 but lower than 0.7 , the impairment loss is mainly concentrated in the third round. Once the discount rate is higher than 0.7 , the speed of risk contagion becomes faster. On the other hand, when the rollover ratio equals 0.8 , risk contagion begins to arise when the discount rate is as high as 0.9 , as shown in Figure 17. The results indicate that the China's banking system is relatively stable if the rollover ratio is high enough.

\section{Conclusions and discussion}

Our investigation of interbank contagion within the Chinese financial sector examines the risk contagion associated with the financial interconnectedness. Although China's financial system is considered to have been less affected by the financial risk in 2008 , the systemic risk is proved to have strong contagion effects. Employing the bilateral exposure, we use the loglog technique and shock simulation to evaluate China's financial system's network structure and contagion effects. As our contribution to the literature on systemic risk, the results indicate that, first of all, due to the strict supervision and high required reserve ratio, the credit shock has little impact on the Chinese financial system. Only two foreign banks are affected when systemic important banks are in distress. As for the bank equity, the impairment loss increases linearly in the first round. When the default loss rate is higher than 0.77 , the asset impairment loss begins to arise in the second round, and does not pass on in the third and fourth rounds. This result is in line with the results of Chen et al. (2020a, b), which argued that credit risk cannot bring about significant risk contagion in Chinese banking sector. However, the liquidity shock has shown more substantial effects than that of the credit shock. This finding is consistent with Chen et al. (2020a, b), which indicates that initial credit default will force the debt bank to fire-sale its external assets and lead to more serious contagion spillover consequences. The discount rate and the rollover ratio have shown opposite effects. The higher the discount rate, the easier it is for banks to be in distress. On the contrary, the larger the rollover ratio, the lower the probability for large-scale bankruptcy in
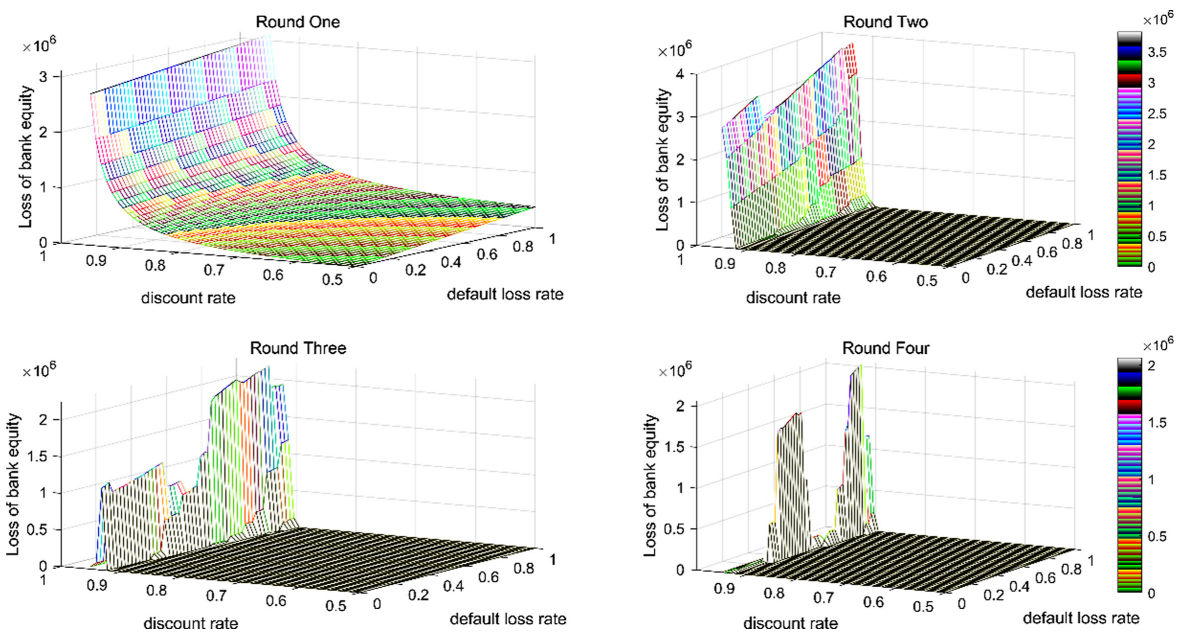

Figure 17.

Loss of bank equity if rollover ratio $=0.8$ 
IJOEM

17,3

910

the banking system. There exists a peak value for the asset impairment loss. The higher the rollover ratio, the higher the discount rate when the peak values arise after the first round. Thirdly, if the credit shock and liquidity shock occur simultaneously, the contagion effects are amplified. This result is in line with Gao and Pan (2012). When the discount rate is low, the number of banks in distress does not increase significantly with the default loss rate. Once the discount rate is large, there will be a high number of bank distress. It indicates that, compared with the default loss rate, the asset discount rate has a higher impact on bank failures. The total volume of asset impairment loss increases with the discount rate initially. When it reaches the peak value, the loss begins to decrease in the following rounds.

These findings imply that, due to the strict supervision and high required reserve ratio, Chinese banks have maintained sufficient equity cushion in order to deal with the potential credit risk. However, if the credit risk overlaps with liquidity risk, the probability of bank failure will be greatly increased, and the systemic risk arises within the banking sector. The effective management of asset portfolio and increased liquidity ratio of banks will be beneficial to prevent the systemic risk contagion. The higher the proportion of banks' liquid assets, the stronger the ability of the bank to resist the systemic risk contagion. On the other hand, under the circumstance of risk propagation, higher rollover rate is useful to reduce the probability of bank failure significantly. Therefore, if the regulator can establish the warning mechanism and propose a timely and proper bailout plan, the adverse effects of risk contagion can be better managed. This provides an important direction for future research. Finally, it is necessary to indicate that the simulated bilateral exposure matrix is not the same as actual transactions, and the contagion effects might be overestimated (Mistrulli, 2011). An actual bilateral exposure data is better to evaluate the systemic risk contagion effects. Chinese financial institutions have been deeply involved with global financial market, and the present research may not accurately represent global banking system as a whole. For further studies, it is valuable to investigate the contagion effect of systemic risk within the global banking system. In addition, it is also worthwhile to evaluate how the bailout policy can reduce the risk propagation and prevent contagious bank failures. The findings in this paper offer a ground view of systemic risks in Chinese banking sector. It may shed light on future research on the systemic risk contagion in the global financial system.

\section{Notes}

1. Source: http://www.gov.cn/jrzg/2009-07/19/content_1369150.htm

2. Total GDP of China in 2020 is 101598.6 billion yuan.

3. The People's Bank of China (PBOC) and the China Banking and Insurance Regulatory Commission (CBIRC) jointly issued the draft version of the "Additional Regulatory Provisions for Systemically Important Banks (Trial)" in April 2021. Additional capital requirement of $0.25 \%$ for group 1 systemically important banks, $0.5 \%$ for group $2,0.75 \%$ for group $3,1 \%$ for group 4 and $1.5 \%$ for group five.

4. In the Haldane and May (2011) framework, IB borrowing and lending relations are assumed to remain fixed, which is on the liabilities side of the balance sheet, not the asset side. it is useful to capture the dynamics of possible system collapse, and keep the IB borrowing or lending static, as a starting point in the investigation.

5. Nier et al. (2007) and Gai and Kapadia (2010) assume $\alpha \approx 1$.

6. In order to liberalize the financial services sector, foreign banks have been allowed to establish branches and access to fund custody business since 2019. It is expected that foreign banks will be more involved into the interbank market business. 
7. Our simulation results proved that the default of any other bank would not result in the failure of other banks.

8. By the end of last year, foreign banks will not be allowed to set up branches in China, and from March this year, they will be allowed to set up branches, which may enhance the ability of foreign banks to resist risks. Credit risk is of little effect (documentation) and reserve requirements result in less risk.

9. When discount rate $\in(0,0.5)$, the number of banks in distress is almost 0 , the contagion effect is weak, therefore it is not showed in the graph. If the discount rate is higher than 0.95, the observation is extreme large, which make the contagion effects difficult to be recognized in the graph.

\section{References}

Ahelegbey, D.F., Giudici, P. and Hashem, S.Q. (2020), "Network var models to measure financial contagion", DEM Working Papers Series.

Amundsen and Elin (2005), Contagion Risk in the Danish Interbank Market, Danmarks National bank, Copenhagen.

Andries, A.M. and Galasan, E. (2020), "Measuring financial contagion and spillover effects with a state-dependent sensitivity value-at-risk model", Risks, Vol. 8 No. 1, p. 5.

Arinaminpathy, N., Kapadia, S. and May, R.M. (2012), "Size and complexity in model financial systems", Proceedings of the National Academy of Sciences of the United States of America, Vol. 109 No. 45, pp. 18338-18343.

Battiston, S., Farmer, J.D., Flache, A., Garlaschelli, D., Haldane, A.G., Heesterbeek, H. and Scheffer, M. (2016), "Complexity theory and financial regulation", Science, Vol. 351 No. 6275, pp. 818-819.

Bayona, A. and Peia, O. (2020), "Financial contagion and the wealth effect: an experimental study", SSRN Electronic Journal, Vol. 1.

Blavarg, M. and Nimander, P. (2002), "Interbank exposures and systemic risk", Risk Measurement and Systemic Risk-Proceedings of the Third Joint Central Bank Research Conference, pp. 287-305.

Censor, Y., Iusem, A.N. and Zenios, S.A. (1998), "An interior point method with bregman functions for the variational inequality problem with paramonotone operators", Mathematical Programming, Vol. 81 No. 3, pp. 373-400.

Chen, B., Li, L., Peng, F. and Anwar, S. (2020a), "Risk contagion in the banking network: new evidence from China", The North American Journal of Economics and Finance, Vol. 54, 101276.

Chen, T., Wang, Y., Zeng, Q. and Luo, J. (2020b), "Network model of credit risk contagion in the interbank market by considering bank runs and the fire sale of external assets", Physica A: Statistical Mechanics and its Applications, p. 542.

Chen, Y., Jin, S. and Wang, X. (2021), "Solvency contagion risk in the Chinese commercial banks' network", Physica A: Statistical Mechanics and its Applications, 126128.

Coval, J.D. and Stafford, E. (2005), "Asset fire sales (and purchases) in equity markets", NBER Working Papers, Vol. 86, No. 2, pp. 479-512.

Dahir, A.M., Mahat, F.B. and Ali, N.A.B. (2018), "Funding liquidity risk and bank risk-taking in BRICS countries: an application of system GMM approach", International Journal of Emerging Markets, Vol. 13 No. 1, pp. 231-248.

Elsinger, H., Lehar, A. and Summer, M. (2006), "Using market information for banking system risk assessment”, SSRN Electronic Journal, Vol. 2 No. 1.

Feng, Y. and Li, X. (2021), "The cross-shareholding network and risk contagion from stochastic shocks: an investigation based on China's market”, Computational Economics, pp. 1-25.

Frisell, L., Holmfeldt, M., Larsson, O., Omberg, M. and Persson, M. (2007), "State-dependent contagion risk: using micro data from Swedish banks", Working Paper, Department of Financial Stability, Sveriges Riksbank. 
IJOEM 17,3

912

Gai, P. and Kapadia, S. (2010), "Contagion in financial networks", Proceedings of the Royal Society A: Mathematical, Physical and Engineering Sciences, Vol. 466 No. 2120, pp. 2401-2423.

Gao, G.H. and Pan, Y.L. (2012), "Financial interlinkages and contagion risk in the interbank market in China”, Journal of Industrial Engineering and Engineering Management, Vol. 26 No. 4, pp. 162-168.

Gorpe, M.Z. , Covi, G. and Kok, C. (2019), "Comap: mapping contagion in the euro area banking sector", IMF Working Papers, Vol. 2019 No. 102.

Haldane, A.G. and May, R.M. (2011), "Systemic risk in banking ecosystems", Nature, Vol. 469 No. 7330 , p. 351.

Hausenblas, V., Kubicová, I. and Leanovská, J. (2015), "Contagion risk in the Czech financial system: a network analysis and simulation approach", Economic Systems, Vol. 39 No. 1, pp. 156-180.

Hellwig, M.F. (2009), "Systemic risk in the financial sector: an analysis of the subprime-mortgage financial crisis", De Economist, Vol. 157 No. 2, pp. 129-207.

Hurd, T.R. (2016), Contagion!: Systemic Risk in Financial Networks, Springer, Berlin, pp. 1-17.

Huynh, T., Nasir, M.A., Nguyen, S.P. and Duong, D. (2020), "An assessment of contagion risks in the banking system using non-parametric and copula approaches", Economic Analysis and Policy, Vol. 65, pp. 105-116.

Kanno, M. (2015), "The network structure and systemic risk in the Japanese interbank market”, Japan and the World Economy, Vol. 36, November, pp. 102-112.

Le, T.H. (2021), "Systemic risk in ASEAN-6: a new empirical investigation", International Journal of Emerging Markets, forthcoming.

Lelyveld, I.V. and Liedorp, F. (2006), Interbank Contagion in the Dutch Banking Sector: A Sensitivity Analysis, MPRA Paper.

Memmel, C. and Stein, I. (2008), Contagion in the German Interbank Market, Deutsche Bundesbank, Frankfurt.

Mistrulli, P.E. (2011), "Assessing financial contagion in the interbank market: maximum entropy versus observed interbank lending patterns", Journal of Banking and Finance, Vol. 35 No. 5, pp. 1114-1127.

Mitchell, M., Pedersen, L.H. and Pulvino, T. (2007), Slow Moving Capital, Social Science Electronic Publishing, Vol. 97, No. 2, pp. 215-220.

Nasir, M.A., Nguyen, S.P. and Duong, D. (2020), “An assessment of contagion risks in the banking system using non-parametric and Copula approaches", Economic Analysis and Policy, Vol. 65, pp. 105-116.

Nier, E., Yang, J., Yorulmazer, T. and Alentorn, A. (2007), "Network models and financial stability", Journal of Economic Dynamics and Control, Vol. 31 No. 6, pp. 2033-2060.

Paltalidis, N., Gounopoulos, D., Kizys, R. and Koutelidakis, Y. (2015), "Transmission channels of systemic risk and contagion in the european financial network", Social Science Electronic Publishing, Vol. 61 No. 1, pp. S36-S52.

Ren, X., Yuan, G.X. and Jiang, L. (2014), "The framework of systemic risk related to contagion, recovery rate and capital requirement in an interbank network", Journal of Financial Engineering, Vol. 1 No. 1, 1450004.

Souza, S.R., Tabak, B.M., Silva, T.C. and Guerra, S.M. (2015), "Insolvency and contagion in the Brazilian interbank market”, Physica A: Statistical Mechanics and its Applications, Vol. 431, pp. 140-151.

Sun, L. (2020), "Financial networks and systemic risk in China's banking system”, Finance Research Letters, Vol. 34, 101236.

Upper, C. (2011), "Simulation methods to assess the danger of contagion in interbank markets", Journal of Financial Stability, Vol. 7 No. 3, pp. 111-125. 
Xlg, A., Xhl, A., Xiong, X. and Wei, Z.B. (2020), "Research on china's financial systemic risk contagion under jump and heavy-tailed risk", International Review of Financial Analysis, Vol. 72, 101584

Yang, L.I., Luo, J. and Jiang, Y. (2021), "Policy uncertainty spillovers and financial risk contagion in the Asia-Pacific network", Pacific-Basin Finance Journal, Vol. 67, 101554.
Risk contagion in Chinese banking network

\section{Corresponding author}

Ming Qi can be contacted at: qiming@cup.edu.cn 